\title{
Shaping the Past and Creating the Future: Music, Nationalism, and the Negotiation of Cultural Memory at Macedonia's Celebration of Twenty Years of Independence
}

\author{
DAVE WILSON
}

\begin{abstract}
:
On September 8, 2011, the Republic of Macedonia commemorated twenty years of independence with an elaborate celebration in capital city Skopje's newly redesigned center square. Against the backdrop of numerous brand-new monuments to Macedonian heroes dating back to Alexander the Great, the event featured performances by the national philharmonic, opera chorus, ballet, and folk ensemble along with stars from various popular music genres. The performances evoked both real and imagined pasts by intertwining musical elements of Macedonian folklore with those of European classical and contemporary popular musical traditions. Based on ethnographic fieldwork among composers, producers, performers, and audiences at several sites of the production of the twentieth anniversary celebration, this article analyzes both state cultural apparatuses and the seemingly contradictory practices of individuals enacting nationalistic cultural memory ideologies to which they do not necessarily subscribe. By bringing together discourses on cultural memory, nationalism, and practice theory with an analysis of three musical performances from the celebration, I argue that in musical performance, individuals and groups who seemingly support the politically powerful can concurrently challenge (and perhaps shape) nationalist agendas, official expressions of identity, and aesthetic strategies for coping with external challenges to the legitimacy of their nation.
\end{abstract}

On September 8, 2011, the Republic of Macedonia celebrated the twentieth anniversary of its peaceful declaration of independence from Yugoslavia in 1991. ${ }^{1}$ The celebration was a spectacle of unprecedented proportions in Macedonia and featured the unveiling of the newly redesigned center square in Skopje, an hour-long speech by Prime Minister Nikola Gruevski, many musical performances, and an audience of Macedonians from all over the country. With Macedonia having faced years of economic challenge, ethnic strife, and political struggle common to many ex-Yugoslav and postsocialist societies, the celebration of twenty years of independence provided Macedonians (in particular the government-appointed organizers) with an opportunity to represent themselves not only to the outside world, but also, and perhaps more importantly, to their fellow citizens. While the celebration may have seemed like a monolithic concretion of a particular representation of Macedonia,

\footnotetext{
${ }^{1}$ The Republic of Macedonia officially changed its name to the Republic of North Macedonia in early 2019. Since this article focuses on a period before the name change, I use Republic of Macedonia and Macedonia throughout.
} 
the production and preparation processes for the musical events of celebration provided myriad sites for the negotiation of this representation. At these sites-rehearsal rooms, recording studios, and informal gatherings - the varied dispositions of participants in the celebration (e.g., musicians, dancers, producers, directors) towards ideas of the nation were more legible than they were on the seemingly unified stage of the highly mediated celebration.

In this article, I discuss the celebration's musical representation of Macedonia as a composite of a range of ideological positions whose production processes allowed for the negotiation of cultural memory narratives involving history, ethnicity, and national identity. Rather than viewing the musical performances themselves as singular representations of state or political party ideologies, I carefully consider the range of dispositions exhibited by participants in the celebration's production processes, demonstrating that such monumental performances of nation reveal multifaceted mechanisms by which nationalism is re-forged and renegotiated. In this case, certain narratives are asserted by the state through its involvement in the design and creation of musical performances to serve political purposes for the future. At the same time, as the celebration's participants and its audience enact and consume the musical elements of the event, they do not affirm a uniform, singular ideology. Instead, they strategically (if subtly) diverge from the nationalism they are promoting, asserting a variety of views regarding the meanings and memories evoked by the event's musical elements. This negotiation of cultural memory involves individuals with varying levels of allegiance to and dependence on the state, including state-appointed directors, employed musicians, and contracted composers from state institutions such as the Macedonian Philharmonic, the Macedonian Opera and Ballet, and the state ensemble of folk songs and dances, Tanec Ensemble, as well as pop stars from a number of genres.

At the marking of Macedonia's twentieth year as a nation-state, the state mobilized its musical employees to express reverence for the past and vision for the future through the lens of specific cultural memory narratives that shape the definition of Macedonianness, which in turn paint a particular picture of the future of the Macedonian nation-state. In his discussion of cultural memory, Jan Assman characterizes it by, among other things, its "distance from the every day," its "concretion of identity," and its "capacity to reconstruct." ${ }^{2}$ He notes that in cultural memory's capacity to reconstruct, it always relates to "an actual and contemporary situation . . . sometimes by appropriation, sometimes by criticism, sometimes by preservation or by transformation." ${ }^{3}$ The musical celebration provides an ideal venue for the state to assert its version of cultural memory as a "concretion of identity" and an attempt to reconstruct the past through the appropriation and transformation of expressive culture in several forms. The event and the accompanying actions of the state also open related discourses of nationalism, national identity, and cosmopolitanism.

By examining the musical production processes leading up to the celebration, the actual musical performances, and the various reactions to the representations of Macedonia on stage in Macedonia's center square (and on televisions throughout the country and diaspora), I hope to reveal the complexity of both state cultural apparatuses and the practices of the individuals embedded in them as they struggle to define and represent the Macedonian nation. These processes play a constituent part of a broader re-

${ }^{2}$ Jan Assman, "Collective Memory and Cultural Identity,” trans. by John Czaplika, New German Critique 65 (1995): 12930.

${ }^{3}$ Ibid. 
narration of the national past that is illustrative of official memory politics that serve (and are shaped by) the interests of the increasingly dominant government. In seeking to bring clarity to these complexities, I analyze the full production process of the musical elements of this celebration based on ethnography conducted in the recording studio and at the performance, where I undertook interviews and engaged in conversations with organizers, producers, musicians, and audience members. In this analysis, I shed light on the strategic processes by which governments integrate music into the shaping of cultural memory in order to advance political ideologies, in this case nationalist ones. I also suggest that individuals and groups with divergent political dispositions participating in these processes often employ agency to influence-and maybe even reduce-the salience of cultural memory narratives being constructed. The performed, sonic making and re-making of cultural memory is thus not an allencompassing nation-building mechanism but, rather, one that is at least to some extent contingent and controvertible.

I situate my analysis in two broader discourses, one dealing with nationalism and the other dealing with social reproduction and transformation, often referred to as practice theory. Ernest Gellner succinctly defines nationalism as "a political principle which maintains that the similarity of culture is the basic social bond," which positions it as a problematic ideology in culturally heterogeneous nationstates such as Macedonia. ${ }^{4}$ Ethnocentric Macedonian nationalist ideologies in many ways reflect this definition, including its boundaries for exclusion that can form the basis for conflict. Historically, Macedonian nationalists have been in conflict_ideological and, occasionally, violent_both with minority ethnic groups and with European and other power players who demand integration and minority rights as preconditions for accessions to international bodies such as NATO and the EU. Elsewhere, Gellner asserts that nationalism is a "very distinctive species of patriotism." $\mathrm{He}$ defines patriotism as general loyalty to and identification with a group that plays a role in the perpetuation of the group. Nationalism for Gellner, then, is a type of patriotism that involves loyalty to a culturally homogenous unit based on a culture striving to be a "high (literate) culture," the ability to sustain an education system that will produce said high culture, and a population that is not constituted by subgroups, but is rather a group of anonymous individuals belonging to the nation by "virtue of [their] cultural style."

In a nation like Macedonia, though its "high culture" has been built largely on the language and practices of ethnic Macedonians, nationalism operates differently than it does in Gellner's theorization. His "culturally homogenous unit" does not exist in reality, as ethnic minorities ("sub-groups") in Macedonia do constitute significant portions of the population as citizens of Macedonia. (According to the 2002 census, ethnic Macedonians constitute $64 \%$ of the population, Albanians 25\%, Turks 4\%, Roma 3\%, Serbs $2 \%$, and others $2 \%{ }^{7}$ ) Yet, while political representation exists across demographics, and linguistic, educational, religious, and other legal rights for minority populations have been maintained and in some cases increased, particularly for Albanians, ethnocentric nationalism in

\footnotetext{
${ }^{4}$ Ernest Gellner, Nationalism (London: Weidenfeld \& Nicolson, 1997), 3.

${ }^{5}$ Gellner, Nations and Nationalism, second edition (Ithaca, NY: Cornell University Press, 2006), 132.

${ }^{6}$ Ibid.

${ }^{7}$ CIA Factbook, "Macedonia," 2012, accessed August 15, 2018, https://www.cia.gov/library/publications/the-worldfactbook/geos/mk.html.
} 
Macedonia continues to rely on other mechanisms of marginalization, such as historically ensuring that the "cultural styles" of minorities are excluded from representation at the national level.

Underlying Gellner's understanding of nationalism is his argument that situates the rise and global spread of the nation-state as related to domestic modernization processes. For him, the "culturally homogenous unit" is required as a work force for industrialization. Other existing literature also relies on modernization to attempt to explain and generalize about the rise and spread of the nation-state, whether with regard to mass literacy engendering the imagining of national communities ${ }^{8}$ or as a result of an increase in direct rule by ethnic others inspiring national uprisings against colonial empires. ${ }^{9}$ More recently, sociologists Andreas Wimmer and Yuval Feinstein challenge this literature, recognizing that while processes of modernization can play significant roles in nation-state formation, each generalization has exceptions. ${ }^{10}$ In the case of Gellner, the faulty presupposition of some sort of uniform society that leads to nation-state formation is troubled by countless counterexamples, though it does reflect ideological imaginings of nationalists and their nationalisms. Wimmer and Feinsteinwhile not denying the ideological power of nationalisms drawing on ethnocentrism, shared language, anti-colonialism, or other factors-argue that nation-state formation does not necessarily result from these ideologies, but rather follows processes of contagion along "established networks of political relationships and cultural similarity." 11

Wimmer, here and elsewhere, clearly distinguishes theories explaining the spread of the nationstate from nationalism as an ideology, while understanding that nationalist ideologies are enmeshed and mobilized in the contagion processes of nation-state formation. He describes nationalism as having many forms (some "better" than others), though all nationalisms are based on the ideological framework that the idea of the nation is "an extended family of political loyalty and shared identity," that "elites and masses should identify with each other and that rulers and the ruled should hail from the same people," 12 and that "members of the nation, understood as a group of equal citizens with a shared history and future political destiny, should rule the state." ${ }^{3}$ The question of who can be included as members of a nation, rule the state, and participate in a nation's shared identity is what is at stake in this celebration of independence in Macedonia, and in similar national commemorations everywhere. At the site of this performance and its production processes, individuals and groups negotiate the notion that a nation consists of citizens who share equality, a history, and a future political destiny with one another. In a situation where elites and masses take a variety of positions on assessing the conditions of equality in the present, asserting representations of the past, and building frameworks

\footnotetext{
${ }^{8}$ Benedict Anderson, Imagined Communities: Reflections on the Origin and Spread of Nationalism (London: Verso Books, 2006).

${ }^{9}$ Charles Tilly, "States and Nationalism in Europe, 1492-1992," Theory and Society 23 (1994), 131-46, https://doi.org/10.1007/BF00993675; Michael Hechter, Containing Nationalism (Oxford: Oxford University Press, 2000), https://doi.org/10.1093/019924751X.001.0001; Michael Mann, "A Political Theory of Nationalism and its Excesses," in Notions of Nationalism, ed. Sukumar Periwal (Budapest: Central European University, 1995), 44-64.

${ }^{10}$ Andreas Wimmer and Yuval Feinstein, "The Rise of the Nation-State across the World, 1816 to 2001," American Sociological Review75, no. 5 (2010), 764-90, https://doi.org/10.1177/0003122410382639.

${ }^{11}$ Wimmer and Feinstein, 786.

${ }^{12}$ Andreas Wimmer, Waves of War: Nationalism, State Formation, and Ethnic Exclusion in the Modern World (Cambridge: Cambridge University Press, 2013), 4, https://doi.org/10.1017/CBO9781139198318.

${ }^{13}$ Andreas Wimmer, "Why Nationalism Works and Why It Isn't Going Away," Foreign Affairs 98, no. 2 (2019), accessed June 11, 2019, https:/www.foreignaffairs.com/articles/world/2019-02-12/why-nationalism-works.
} 
for imagining the future, mechanisms of inclusion and exclusion take center stage.

Engaging with and shaping cultural memory through representations of the past is one of the more obvious tools of exclusion in processes of maintaining ethnocentric nationalism in a multi-ethnic nation. Although I disagree with Anthony Smith's premise that nations have ancient roots in longenduring ethnicities, his description of nation-building mechanics and techniques shows an understanding of how nationalists engage the past to create ideas of a shared future destiny. He states:

"nation-building" is not simply a matter of establishing the appropriate institutions or generating a complex class structure . . . it involves ceaseless re-interpretations, rediscoveries and reconstructions; each generation must re-fashion national institutions and stratification systems in light of the myths, memories, values and symbols of the "past," which can best minister to the needs and aspirations of its dominant social groups and institutions ... the often-fictitious genealogies and the myths attaching to heroes and monuments ... [help] to shape the nation, locate its borders and chart its destiny. ${ }^{14}$

Nationalists, then, release and/or manipulate-in Assman's terms-cultural memory's capacity to reconstruct, so that it can do the work of appropriation, transformation, and the concretion of identity. Anti-colonialism has long played a powerful role in buttressing ethnocentric Macedonian nationalist ideology, grounding it in a constructed cultural memory of a centuries-long Ottoman oppression of an ethnic Macedonian people who endured and eventually overcame this oppression. This is a classic nationalist reconstruction of the past wherein an ethnocentric national identity relies on erasure of multi-ethnic, multi-lingual realities in narrating historical events. ${ }^{15}$ With Ottoman Turks thus constructed as Other (and former colonizer), anti-Turkish and associated anti-Muslim or anti"Oriental" tropes can be mobilized in the concretion of ethnocentric Macedonian national identity in powerful ways. In my examination of the production of musical representations of the Macedonian nation at the twenty years of independence celebration, I highlight the leveraging of these tried-andtrue tropes along with other elements of the celebration that are clear examples of attempts at reinterpretations, rediscoveries, and reconstructions that seek to chart Macedonia's destiny. Significant, but less obvious, are the subtle but noteworthy contestations of those attempts by multiple social actors on the ground.

In a bridge between theories of nationalism and practice theory, Pierre Bourdieu briefly addresses what he terms "nationalist passion," asserting that such ideologies persist because they are "bound to the body in the form of disposition." 16 Such bodily dispositions or beliefs are part of his habitus concept; they cannot be extirpated "without transformation of the conditions of the production and

\footnotetext{
${ }^{14}$ Anthony D. Smith, The Ethnic Origins of Nations (Oxford, UK: Basil Blackwell, 1988), 206-7.

${ }^{15}$ During the time of the Ottoman Empire, geographic Macedonia was the home of numerous religions and languages, not only Orthodox Christian Slavic-speakers who considered themselves Macedonian. Even some members of the group of established heroes in the canonized foundational revolution of the Macedonian nation were not ethnic Macedonians. One of these heroes was Pitu Guli, a Vlah who is celebrated in numerous Macedonian folk songs as well as the national anthem. For a study in the ongoing construction of Macedonian nationalist cultural memory in this vein, see Keith Brown, The Past in Question: Modern Macedonia and the Uncertainties of Nation (Princeton, NJ: Princeton University Press, 2003).

${ }^{16}$ Pierre Bourdieu, Pascalian Meditations (Stanford, CA: Stanford University Press, 2000), 181.
} 
transformation of dispositions." 17 These bodily dispositions of both patriotism and nationalism in Macedonia are evident in the production and reproduction of memory politics for the celebration, though the social actors involved seem to exhibit a number of contradictions in their practice with regard to the nationalism they are performing. As Macedonian (or any other) society is not as uniform as Gellner would presuppose (or as ethnocentric nationalists may desire), to account for these seeming contradictions, it is useful to recognize that a multiplicity of structures exists for any society, and that various structures operate within even a single sphere. In his development of practice theory, historian and social theorist William Sewell asserts that due to a multiplicity of structures, "knowledgeable social actors whose practices constitute a society" are "versatile" and "capable of applying a wide range of different and even incompatible schemas and have access to heterogeneous arrays of resources." 18 The participants in Macedonia's celebration of independence indeed reveal themselves to be knowledgeable social actors, proving to vary widely on the intensity or even substance of their nationalist passions. They employ versatile practices to negotiate the cultural memory asserted by the state in their own performances while they simultaneously enact the performances without directly challenging state narratives and thus jeopardizing their employment status and livelihoods.

The musicians, dancers, choreographers, directors, composers, producers, and public officials involved in the production of Macedonia's celebration of twenty years of independence occupy diverse positions of power in their respective fields, and possess varied political and nationalistic ideologies that do not always align with official positions. Some are intellectual, political, or musical elites (including composers, pop singers, and featured soloists), while others are middle class employees of state ensembles. In the context of a complex society full of multiple and overlapping ethnic, political, and economic structures, these actors, through their musical and social creativity, demonstrate social versatility and the ways that individuals in various positions of power in a given field can cope with and even influence representations, definitions, and ideas of nation.

In several instances, individuals in these various positions explicitly invoked the concept of cosmopolitanism with regard to the celebration, employing it to situate favorably themselves, the performance, and/or the ideas represented by the performance. Because cosmopolitanism is contextdependent and can be discursively deployed in any number of slippery ways even in the same context, it is a useful tool in the hands of actors and institutions navigating ideological terrain that encompasses values for both the nationalistic celebration of a state and the accommodation required in the context of a multi-ethnic state with ambiguous ambitions for EU membership. In some ways, the discursive use of "cosmopolitan" can be read as a descriptor that distinguishes the Macedonia of 2011 from the Macedonia of the socialist Yugoslav period (1945-1991) and before. That is, the very ability to evoke and construct cultural memory is characterized as cosmopolitan by those involved in its evocation and

\footnotetext{
${ }^{17}$ Ibid., 180. Bourdieu defines habitus as “systems of durable, transposable disposition," Bourdieu, The Logic of Practice (Stanford, CA: Stanford University Press, 1990), 53. Patriotism is a durable disposition among Macedonians.

${ }^{18}$ William H. Sewell, Jr., Logics of History: Social Theory and Social Transformation (Chicago: University of Chicago Press, 2005), 140, https://doi.org/10.7208/chicago/9780226749198.001.0001. For more on how Sewell's conception of agency sits within post-structural discourses of practice theory, see Sewell, 127-145, where he expands on Anthony Giddens' notion of the duality of structure composed of schemas and resources, and Sherry Ortner, Anthropology and Social Theory: Culture, Power, and the Acting Subject (Durham, NC: Duke University Press, 2006), 134-39, https://doi.org/10.1215/9780822388456.
} 
construction; the content of the constitutive elements of the performed cultural memory on its own is positioned, thus, not as cosmopolitan but rather as primitive and primordial, available to the cosmopolitan to assemble and manipulate in service of any number of ideologies. For these reasons, and because the term was used prominently in public descriptions of the celebration, I devote a later part of this article to a more detailed analysis of its usage.

Before I examine the individual actors and the musical texts and processes in which they participated for the celebration in detail, I will provide some historical context and background for the development of Macedonian nationalism and its expression in cultural forms. In particular, I will focus on the Tanec Ensemble, not only because of its prominent participation in the twentieth anniversary of independence celebration performances, but also because its historical development as an ensemble provides key insight into the ideological roots of Macedonian nationalism as expressed through music.

\section{Musical Nationalist Ideology under Yugoslavia and the Growth of Macedonian Nationalism}

Macedonia's transition from a socialist Yugoslav republic to an independent nation-state relocated centralized state power from the Yugoslav capital, Belgrade, to the Macedonian capital, Skopje. Though this transition is marked by the national referendum on September 8, 1991, when $96 \%$ of voters elected to make Macedonia an independent and sovereign nation-state, it was part of broader changes in the European geo-political landscape beginning at least in the early 1980s, if not before. ${ }^{19}$ Because of the relatively high autonomy of Yugoslav republics, especially after the Constitution of 1974, the republics officially had the status almost of independent states. Significant power was located at the republic level, and Macedonia (like the other five republics) was regarded as a nation in the context of the broader Federal Yugoslav state. Despite the seemingly sudden transformation from constituent Yugoslav republic to independent nation-state, I follow scholars who argue that socialist systems promoted national consciousness and institutionalized "both territorial nationhood and ethnocentric nationality as basic cognitive and social categories" over long periods of time. ${ }^{20}$ I argue that this shift of power did not bring about a new national ideology, but rather continued ethnonational elements of Yugoslav policy, which had fostered local national ideologies for each of its constituent republics. ${ }^{21}$ Aspects of this policy mandated the performance of stylized folk practices in music, dance, dress, and other aesthetic expressions in the context of official state representations of Macedonia. The most relevant example of this policy is the 1949 founding of Tanec Ensemble, a key ensemble in the performances celebrating

\footnotetext{
${ }^{19}$ Dieter Nohlen and Philip Stöver, Elections in Europe: A Data Handbook (Baden-Baden, Germany: Nomos, 2010), 1278, https://doi.org/10.5771/9783845223414.

${ }^{20}$ Rogers Brubaker, Nationalism Reframed: Nationhood and the National Question in the New Europe (New York: Cambridge University Press, 1996), 8, https://doi.org/10.1017/CBO9780511558764; see also, e.g., Ivo Banac, The National Question in Yugoslavia: Origins, History, Politics (Ithaca, NY: Cornell University Press, 1984); Anthony Oberschall, “The Manipulation of Ethnicity: From Ethnic Cooperation to Violence and War in Yugoslavia," Ethnic and Racial Studies 23, no. 6 (2000): 982-1001, https://doi.org/10.1080/014198700750018388.

${ }^{21}$ Alongside nationalist ideals during the Yugoslav period, the Yugoslav ideal of "brotherhood and unity" governed policies of inter-ethnic relations. This policy established equality and peaceful coexistence of ethnic minorities and dominant populations in each republic, though the dominant "national" group (e.g., ethnic Macedonians) in every case was represented at the national level.
} 
Macedonia's twenty years of independence. ${ }^{22}$ Tanec's formation involved the adaptation of folk songs and dances for the stage to represent Macedonian folk culture for domestic and international audiences. The ensemble won first prize at the Llangollen, Wales, international folk dancing competition in 1950, and embarked on a tour of the United States in 1956 as the "Yugoslav National Folk Ballet," as required of all Yugoslav folk music and dance ensembles. ${ }^{23}$ The official program of that tour provides myriad examples that demonstrate the fostering of a national ethnic Macedonian identity within Yugoslavia and on the international stage. A section of the program titled "'Tanec' Means Dance-All Kinds of Dance: The Repertory" reads:

Macedonians have a long, unbroken history-literally and in the dance. And these dancedramas of the Macedonians go back in time to the earliest ritual of pre-Slav tribes and to pre-classic Greek periods ... They preserve elements from their own Greek ascendancy under Philip and Alexander, of the Roman Empire, two eras of Byzantine rule, medieval feudalism, the Ottoman Empire, the Austro-Hungarian Empire. Slaves of every empire, they have preserved their national unity and identity ... in their dance. ${ }^{24}$

The rhetoric here suggests that a historically unverifiable ethnocentric Macedonian nationalist ideology developed early on in the context of socialist Yugoslavia, promoted and nourished by stylized performances of musical folklore and the narratives constructed around them. This narrative implies an ancient Macedonian people characterized by oppression and seemingly pre-dating all history as an enduring, unified, unchanging population. ${ }^{25}$ Although representation of Yugoslavia in a supranational sense typically rendered Macedonia invisible in international forums such as diplomacy and sports, as well as among pan-Yugoslav news media outlets and film, ${ }^{26}$ the presence of these local narratives of ethnocentric national identity reveal the early seeds of contemporary Macedonian nationalism. Furthermore, as Ana Hofman elucidates, Yugoslav multinational identity was built not on folk music, but on zabavna muzika (entertainment/popular music in rock and other styles), leaving folk music at the local (smaller towns and villages) level under the jurisdiction of the officials of each republic to administer and shape in official contexts. ${ }^{27}$ This republic-level regulation also applied to emergent local zabavna muzika styles, which were controlled and shaped in ways that conformed to aesthetic ideals of

\footnotetext{
${ }^{22}$ For histories of Tanec, see Elsie Ivančić Dunin and Stanimir Višinski, Dances in Macedonia: Performance Genre, Tanec (Skopje: Open Society Institute Macedonia, 1995); Ivona Opetčeska Tatarčevska, “ The Idea Behind Our Folk Dances': Public Narratives About Folk Dances in Macedonia," in ICTM Study Group on Music and Dance in Southeastern Europe: Proceedings 2010 Symposium Izmir, Turkey, ed. Elsie Ivančić Dunin (Izmir, Turkey: ICTM Study Group on Music and Dance in Southeastern Europe, 2010), 78-85.

${ }^{23}$ Dunin and Višinski, 10; Albert Kinert and Dragutin Zdunić, Folklor Naroda Jugoslavije (Zagreb: Grafički Zavoda Hrvatske, 1963).

24 "Yugoslav National Folk Ballet (Tanec): First American Tour," official concert program (New York: Lou Dunetz and Paul Lovett, 1956).

${ }^{25}$ Cf. Smith, The Ethnic Origins of Nations.

${ }^{26}$ Zala Volčič, "Yugo-Nostalgia: Cultural Memory and Media in the Former Yugoslavia," Critical Studies in Media Communication 24, no. 1 (2007), 23, https://doi.org/10.1080/07393180701214496.

${ }^{27}$ Ana Hofman, Staging Socialist Femininity: Gender Politics and Folklore Performance in Serbia (Boston: Brill, 2011), https://doi.org/10.1163/ej.9789004191792.i-148.
} 
the national. ${ }^{28}$ Thus, as Yugoslavia crumbled in the 1980s (the "collapse of the superculture" as Mirjana Laušević has it), Macedonian national ideology and its associated musical symbols were poised to take center stage in the cultural representation of the new independent Macedonian nation-state. ${ }^{29}$

When Macedonia gained its independence in 1991, national ideology persisted broadly in a form of moderate nationalism closer to patriotism, as it involved a sense of pride in identifying as an ethnic Macedonian but fell short of passionate, violent forms of nationalism. ${ }^{30}$ However, other, less moderate forms of nationalism persisted in response to, among other things, diplomatic opposition from Greece, which feared that Macedonia would reassert nationalist claims to the land of Greek Macedonia dating back to pre-World War I borders. This opposition emerged from the already decades-long struggle wherein Greek challenges to a distinct Macedonian ethnic identity and the legitimacy of a Macedonian nation came into conflict with Macedonian nation-building processes under socialist Yugoslavia. ${ }^{31}$ After Macedonia's 1991 secession from Yugoslavia, Greece refused to recognize Macedonia under its constitutional name (the Republic of Macedonia) and placed a trade embargo on the new state. Implicitly referencing the empire of Alexander the Great, Greece has consistently claimed cultural ownership of Macedonia's symbols, history, geography, and most importantly, its name. In the 1995 Interim Accord designed to quell the tensions between the two nations, Greece agreed to lift the trade embargo and to cease its veto of Macedonian membership in international organizations under a few conditions, including the adoption of the name "Former Yugoslav Republic of Macedonia" (FYROM) for use in international forums, and the removal of the Vergina sun, a reference to Alexander the Great's legacy, from the Macedonian flag. More recently, at the 2012 NATO Summit in Chicago, the alliance refused to consider Macedonia's accession into NATO until it was able to resolve the name issue with member-state Greece. ${ }^{32}$

Though these struggles with Greece stretch back far into the Yugoslav period, they increasingly dominated Macedonian public and private discourse after its 1991 independence. The center-right party in power at the time of the twentieth-anniversary celebration, the Internal Macedonian

\footnotetext{
${ }^{28}$ For more on the tension between zabavna muzika and traditional and regional musics, especially in the 1980 s and 1990s, see Brana Mijatovic, “The 'Supermen' and the 'Normal People': Music, Politics, and Tradition in 1990s Serbia," Selected Reports in Ethnomusicology 12 (2005), 203-18; Ljerka Vidić Rasmussen, "The Southern Wind of Change: Style and the Politics of Identity in Prewar Yugoslavia," in Retuning Culture: Musical Changes in Central and Eastern Europe, ed. Mark Slobin (Durham, NC: Duke University Press, 1996), 99-116, https://doi.org/10.1215/9780822397885-007; Jane C. Sugarman, “The Criminals of Albanian Music': Albanian Commercial Folk Music and Issues of Identity since 1990,” in Balkan Popular Culture and the Ottoman Ecumene: Music, Image, and Regional Political Discourse, ed. Donna A. Buchanan (Lanham, MD: Scarecrow Press, 2007), 275-281.

${ }^{29}$ Mirjana Laušević, “The Ilahiya as a Symbol of Bosnian Muslim National Identity," in Retuning Culture: Musical Changes in Central and Eastern Europe, ed. Mark Slobin (Durham, NC: Duke University Press, 1996), 121, https://doi.org/10.1215/9780822397885-008.

${ }^{30}$ Macedonia declared its independence from Yugoslavia peacefully; conflicts involving the Albanian minority came later.

${ }^{31}$ For a more thorough discussion of Yugoslav-era policies about ethnic Macedonians in northern Greece (especially related to music), and the broader Macedonian Question, see Dave Wilson, "Music Making Space: Musicians, Scenes, and Belonging in the Republic of Macedonia," PhD diss., University of California, Los Angeles (2015), 19-29.

${ }^{32}$ See also Loring M. Danforth, The Macedonian Conflict: Ethnic Nationalism in a Transnational World (Princeton, NJ: Princeton University Press, 1995); Hugh Poulton, Who are the Macedonians? (Bloomington: Indiana University Press, 1995); Brown, The Past in Question; Andrew Rossos, Macedonia and the Macedonians: A History (Stanford, CA: Hoover Institution Press, 2008). The name issue did not progress until negotiations between Greece and Macedonia moved the issue forward in 2018. Though a subsequent referendum in Macedonia to ratify a potential name change failed due to low voter turnout, the Macedonian Parliament initiated a process to change its constitutional name to "The Republic of North Macedonia” in 2018, and the change was finalized in 2019.
} 
Revolutionary Organization-Democratic Party for Macedonian National Unity (Vnatrešna makedonska revolucionerna organizacija-Demokratska partija za makedonsko edinstvo or VMRODPMNE), founded in 1990, capitalized on strong anti-Greek sentiments in winning and maintaining a majority in Parliament since 2006. VMRO-DPMNE's less moderate nationalism focuses on a new definition of Macedonian ethno-genesis-an amalgamation of ancient Macedonian and Slavic roots with an emphasis on the former-in conjunction with classic nationalist employment of ancient myths, memories, and symbols to legitimate the validity of a nation's existence. ${ }^{33}$ As with many ethnocentric nationalisms, Macedonian nationalism over the last twenty years has exacerbated ethnic tension, primarily with the Albanian population. A deadly civil conflict among Macedonians and Albanians took place in 2001, resulting in 150-250 deaths and nearly 1,000 total casualties. ${ }^{34}$ The conflict came to an end with the August 2001 Ohrid Framework Agreement, which stipulated the implementation of policies in government and education that increased representation and rights of Albanians and other minorities. ${ }^{35}$ VMRO-DPMNE continued the implementation of the Ohrid Framework policy changes, and at times used rhetoric that included ethnic minorities in discussions of what constitutes the Macedonian nation. Even so, the party's cultural policies continued to express an ethnocentric nationalist ideology, as demonstrated in numerous projects including increased investment in and promotion of Tanec and other national musical ensembles, and at the celebration of twenty years of Macedonian independence.

\section{The "Skopje 2014" Project in Public and Private Discourse}

When I arrived in Skopje in June 2011, I had not spent substantial time in Macedonia since I had completed two years working there full-time at a non-profit organization in 2004. The day I arrived, I found a torn-up central square and a crane erecting an enormous equestrian statue of Alexander the Great to its mount on top of a grand fountain. This monument is the central object of the "Skopje 2014" project, VMRO-DPMNE's controversial redesign of Skopje's center featuring the construction of museums and other buildings with neo-classical facades, the Porta Makedonija (Macedonia Gate, loosely modeled on the Arc de Triomphe), and dozens of statues of Macedonian national heroesGoce Delčev, Kočo Racin, Philip II, and others-whose lineage is also claimed by either Bulgaria or Greece. The central Alexander the Great fountain (officially titled "Warrior on a Horse") stands taller and larger than a similar statue of Alexander on Thessaloniki's Aegean Sea waterfront, and towers above its surrounding buildings. Throughout the 2011 summer, I casually observed the construction of the Alexander fountain and several other statues when I would pass through the square. In July, I learned that the September 8 celebration would also be the unveiling and dedication of the new fountain and

\footnotetext{
${ }^{33}$ Ivan Dodovski, "Pride and Perplexities: Identity Politics in Macedonia and Its Theatrical Refractions," in After Yugoslavia: Identities and Politics within the Successor States, ed. Robert Hudson and Glenn Bowman (New York: Palgrave Macmillan, 2012), 93, https://doi.org/10.1057/9780230305137 6; Vasiliki P. Neofotistos, "Going Home to Pakistan: Identity and Its Discontents in Southeastern Europe,” Identities 18, no. 4 (2011), 291-316, https://doi.org/10.1080/1070289X.2011.654102.

${ }^{34}$ John Phillips, Macedonia: Warlords And Rebels in the Balkans (New Haven, CT: Yale University Press, 2004$), 161$.

${ }^{35}$ See also Neofotistos, The Risk of War: Everyday Sociality in the Republic of Macedonia (Philadelphia: University of Pennsylvania Press, 2012), https://doi.org/10.9783/9780812206562.
} 
the entire redesigned square. Though the project was named Skopje 2014, the 2011 celebration was the principal event marking the project, and new elements continued to be added even after 2014 .

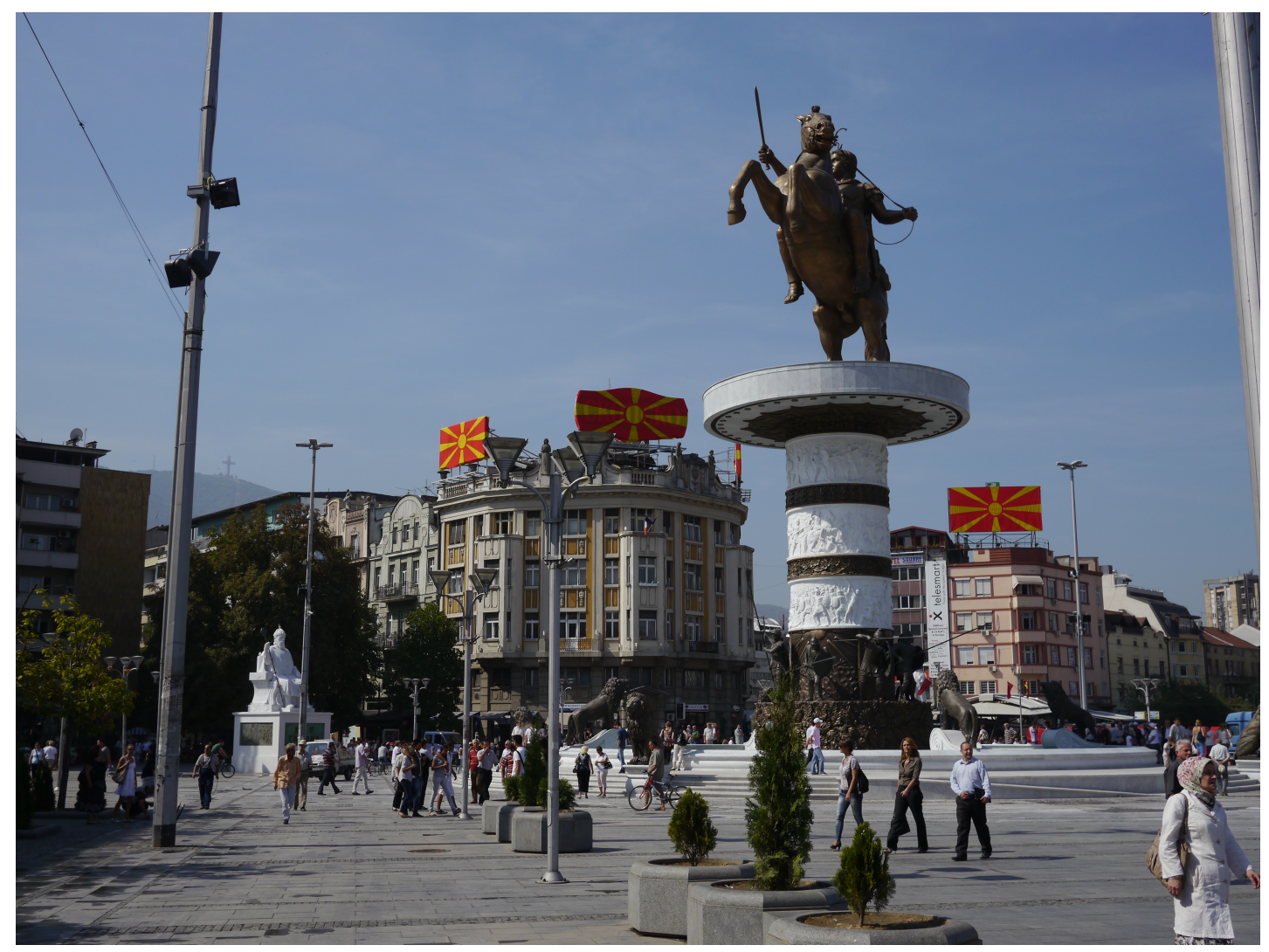

Figure 1: "Warrior on a Horse" in Skopje's central square, September 2011. Photo by the author.

VMRO-DPMNE, through this forceful reconfiguration of public space driven by an imagining of an ancient past, asserted a specific narrative of Macedonian history, literally constructing a cultural memory in the form of a spatial memorialization for Macedonia consistent with the aforementioned amalgamation of Slavic and ancient Macedonian roots. Today the buildings and monuments of the Skopje 2014 project have come to dominate Macedonia's central public space, leaving no doubt as to the official VMRO-DPMNE narrative of Macedonian history. ${ }^{36}$ The party, through this project, engaged in nation-building as defined by Smith, attaching genealogies to heroes and monuments as well as employing memories, values, and symbols of the reinterpreted past to "minister to the needs and aspirations of its dominant social groups." ${ }^{37}$ VMRO-DPMNE made great efforts to shape the

\footnotetext{
${ }^{36}$ Cf. Božidar Jezernik, "No Monuments, No History, No Past: Monuments and Memory," in After Yugoslavia: Identities and Politics within the Successor States, ed. Robert Hudson and Glenn Bowman (New York: Palgrave Macmillan, 2012), 182-91, https://doi.org/10.1057/9780230305137_12. As this configuration of space promotes Macedonian nationalism and upholds ethnic divisions, Pierre Nora's concept of les lieux de mémoire (realms, sites, or places of memory) is also useful, as he posits that certain sites are able to inculcate and embody particular memories of the nation. See Pierre Nora, Les Lieux de Mémoire [Realms of Memory], Vol. 2, La Nation [The Nation] (Paris: Gallimard 1986); Nora, "Between Memory and History: Les Lieux de Mémoire," Representations 26 (1989), 7-25, https://doi.org/10.2307/2928520. ${ }^{37}$ Smith, 206.
} 
Macedonian nation, charting its destiny and locating the borders of its cultural memory to include the pre-Slavic Alexandrian past as its primary and most significant heritage. This suited the party's needs and aspirations for maintaining and increasing power as greater dissatisfaction with Greek policy among Macedonians has often aligned with nationalistic ideologies and led to greater public support.

Perspectives I elicited from Macedonians regarding the new square in 2011 varied from pride to disinterest to disdain, and even though many Macedonians described it as "kitsch," a good number at the time seemed able to find some positive aspect of the project (e.g., the beauty of the fountain, the improvements to streets and other infrastructural elements in the Skopje center). Relatively soon after the project was announced, in 2009 and 2010, small protests were organized by groups such as "Prva Arhi Brigada" (First Archbrigade, a group of architecture university students against the aesthetics of the project) and "Raspeani Skopjani" (Singing Skopjans), but such public protests were small in size and limited in actual effects on policy. Despina Angelovska discusses such protests as "significant public counter-reactions" to the Skopje 2014 initiative and as "reshaping and correcting the imposed politics of memory." ${ }^{38}$ From what I witnessed, hers was an overly optimistic view, at least from the vantage point of early public protests. Around the time of the unveiling of the Alexander fountain in 2011, public criticism of the project was anything but significant and, though many citizens maintained a cultural memory divergent from that advanced by the project, their voices in no way "reshaped" or "corrected" the memory politics of the state. In contrast to these small protests and to the subtle but significant practices of non-party-aligned actors involved in the twentieth-anniversary celebration, massive antigovernment protests related to a number of issues began to occur in 2014. These protests indicated the broad emergence, years after the 2011 celebration, of more openly resistant forms of opposition and signaled a shift in a number of power relations; VMRO-DPMNE was voted out of power in 2016.

Prior to the 2014 emergence of widespread resistance, protest more commonly took a more muted form, one that mitigated risk but still made space for oppositional positions. The practice of muted protest was honed during the Yugoslav period and continued to be useful in independent Macedonia, particularly during the period when VMRO-DPMNE was increasing its dominance. Press censorship steadily increased in Macedonia between 2009 and 2015, and individuals who openly criticized government projects were imprisoned or their businesses fined or closed, allegedly for unrelated reasons. ${ }^{39}$ In addition, because of Macedonia's relatively small population (approximately two million), ${ }^{40}$ networks of employment were tight-knit and, during this time period, becoming more integrated with the VMRO-DPMNE party organization. As a result, there was great reticence to openly

\footnotetext{
${ }^{38}$ Despina Angelovska, “(Mis)representations of Transitional Justice: Contradictions in Displaying History, Memory, and Art in the Skopje 2014 Project," in The Arts of Transitional Justice: Culture, Activism, and Memory after Atrocity, ed. Peter Rush and Olivera Simić, (New York: Springer, 2014), 193, 194, https://doi.org/10.1007/978-1-4614-8385-4_10. See also Fabio Mattioli, "Regimes of Aesthetics: Competing Performances Surrounding the Skopje 2014 Plan," in Mirroring Europe: Ideas of Europe and Europeanization in Balkan Societies, ed. Tanja Petrović (Leiden: Brill, 2014), 64-87, https://doi.org/10.1163/9789004275089 005; and Andrew Graan, "Counterfeiting the Nation?: Skopje 2014 and the Politics of Nation Branding in Macedonia," Cultural Anthropology 28, no. 1 (2013), 161-79, https://doi.org/10.1111/j.1548-1360.2012.01179.x.

${ }^{39}$ Macedonia's ranking on the Press Freedom Index among 179 nations steadily declined from 34 in 2009 to 123 in 2014 (see http://en.rsf.org/press-freedom-index-2013,1054.html, accessed January 28, 2014). The Global Press Freedom Rankings (2013) ranked Macedonia at 120 out of 197 nations with its lowest score to date (see http://www.freedomhouse.org/report-types/freedom-press, accessed January 28, 2014).

${ }^{40}$ CIA Factbook.
} 
share criticism of state projects and ideologies, especially as the party-directed state increased its influence in more and more arenas of Macedonian society.

This reticence was at least in part undergirded by economic precarity. Beginning in the 1990s, a downwardly-mobile middle class emerged in Macedonia due in part to stagnant wages and rising costs. The 2008 global financial crisis afforded Prime Minister Gruevski the opportunity to access international credit, which he and the VMRO-DPMNE government used to bolster the party's control through, for example, increasing the budget of the Administration for Security and Counterintelligence (UBK) tenfold to foster a climate of fear and silence, and funneling funds to oligarchs through construction projects like Skopje 2014. ${ }^{41}$ But widespread liquidity was not generated, wages continued to stagnate, and employment in public sector or VMRO-DPMNE-associated private firms was difficult to obtain without party loyalty. In addition, being awarded a permanent contract of employment in a public sector job at a school, university, or hospital frequently required an extended period of volunteering without pay. In an environment of illiquidity, many were willing to volunteer their labor for months or years, as one of the principal benefits to a permanent employment contract was eligibility for a consumer loan or mortgage. ${ }^{42}$ Employees of state music ensembles like Tanec and the Macedonian Philharmonic lived on the brink of this kind of precarity, and for the most part were not willing to risk losing employment by making known any dissatisfaction with the VMRO-DPMNE party.

The partyocratic ${ }^{43}$ environment fostered by VMRO-DPMNE, where voicing public criticism of the state came with serious risks, fostered the development of generally separate discourses in the public and private spheres regarding state projects and policies. In public forums and in the presence of known party members and allies, individuals tended to avoid negative valuations of government projects and only participated in such projects if required by their employment (such as the musicians employed by state musical ensembles), using strategies such as irony to perform the bodily dispositions imposed on them (described further below). The discourse in the public sphere was generally neutral relative to affirmation of state projects, as individuals took a benign stance on such projects when in proximity to those in positions of political power. ${ }^{44}$ In the private sphere, away from the politically powerful and in conversation among trusted friends and associates, criticism of government identity and memory politics abounded as an affirmation of patriotism and a contestation of new forms of nationalism. Among acquaintances and strangers, such discourse was often subtle and embedded more in what was not said than what was said. For example, if topics of government projects arose in my conversations with strangers I met such as taxi drivers, café workers, or even with new friends (i.e., in relationships where trust had not been built), I often heard comments such as "well, we don't need to

\footnotetext{
${ }^{41}$ Fabio Mattioli, "Financialization without Liquidity: In-kind Payments, Forced Credit, and Authoritarianism at the Periphery of Europe," Journal of the Royal Anthropological Institute 24 (2018), 578-81, https://doi.org/10.1111/14679655.12861.

${ }^{42}$ In the early 2000s, European (particularly Greek) financial institutions took over Macedonia's banking system, and credit conditions eased rapidly; see Mattioli "Financialization," 580.

${ }^{43}$ A partyocracy (also partiocracy, partocracy) is a society ruled by a dominant political party. In this case, VMRODPMNE increased its dominance by intertwining the mechanisms of its party organization with those of the state.

${ }^{44}$ For a comparative case of "nonparticipation” as a form of political agency in Serbia, see Jessica Greenberg, “There's Nothing Anyone Can Do about It': Participation, Apathy, and 'Successful' Democratic Transition in Postsocialist Serbia," Slavic Review 69, no. 1 (2010), 41-64, https://doi.org/10.1017/S0037677900016697.
} 
speak about politics," or to "not speak about that subject too much." Nothing was actually said, but the tone of the comments and non-verbal cues expressed disdain and an assumption that I would similarly view the ideologies and projects of VMRO-DPMNE in a negative light.

The issue of a distinction between public and private is not a new one in postsocialist nationstates such as Macedonia; socialist-era societies played host to similarly divergent spheres. Many scholars of state-socialism and postsocialism have dealt with the public/private distinction in one form or another, and each case represents a specific variation on the way public and private actions and discourses play out. ${ }^{45}$ Susan Gal draws on her work in socialist Eastern Europe to suggest that public/private distinctions are nested within one another, and can range from fixed and stable to ephemeral and contingent. ${ }^{46}$ In the case of Macedonia, the divergent and nested public and private discourses with regard to government projects continues from the Yugoslav era in adapted form. ${ }^{47}$ In the examples from the celebration that follow, individuals varied between public and private discourses, adjusting their rhetoric and stated opinions depending on the setting. In this way, they maintained their patriotic dispositions (in private), even as they performed nationalistic state forms of musical expression (in public, either enacting a sense of irony or simply executing the musical labor required by their employment).

\section{Music-Making at the Celebration of Twenty Years of Independence}

My research in the summer of 2011 centered on fieldwork with Tanec, as I observed rehearsals and performances in Skopje and learned about their repertoire and musical and dance practices. I spent the early months of the summer building relationships with the newly appointed director, Zoran Džorlev, his staff, and various members of the ensemble, and later was invited to travel with the ensemble to several performances in Macedonian regional towns. Midway through the summer, I learned along with the ensemble members that Tanec would be performing several pieces at the September 8 celebration, and I made plans to be present in some recording sessions for the pieces as well as backstage with the performers at the celebration itself. Members of Tanec played a prominent role in the three central performances of the celebration, generally representing ethnic Macedonian folk traditions and the associated nationalistic ideals through their music, dance, and traditional attire in a performance of the bodily dispositions of their patriotic habitus.

In the broader context of the celebration, these representations constituted only one element among many others including representations of the European symphonic tradition and popular music. The various combinations of musical and dance styles in each performance piece communicated a complex set of ideologies and discourses about the Macedonian nation. A close examination of the pieces and their production processes reveals much, not only about those ideologies and discourses, but

\footnotetext{
${ }^{45}$ Cf., e.g., Katherine Verdery, What Was Socialism, and What Comes Next? (Princeton, NJ: Princeton University Press, 1996); Jeff Weintraub and Krishan Kumar, eds., Public and Private in Thought and Practice: Perspectives on a Grand Dichotomy (Chicago: University of Chicago Press, 1997).

${ }^{46}$ Susan Gal, "A Semiotics of the Public/Private Distinction," differences: A Journal of Feminist Cultural Studies 13, no. 1 (2002), 77-95, https://doi.org/10.1215/10407391-13-1-77.

${ }^{47}$ See Hofman, "Socialist Stage," for an example of the politics of Yugoslav-era Serbian conceptions of public and private musical expression.
} 
also about the knowledgeable and versatile actors (to use Sewell's term) promoting and endorsing them. These actors, in the exercise of their agency, communicated ideas about how they viewed themselves as Macedonians and how they viewed the Macedonian nation-ideas often in dissonance with the views they were performing on behalf of the state.

\section{"Makedonija"}

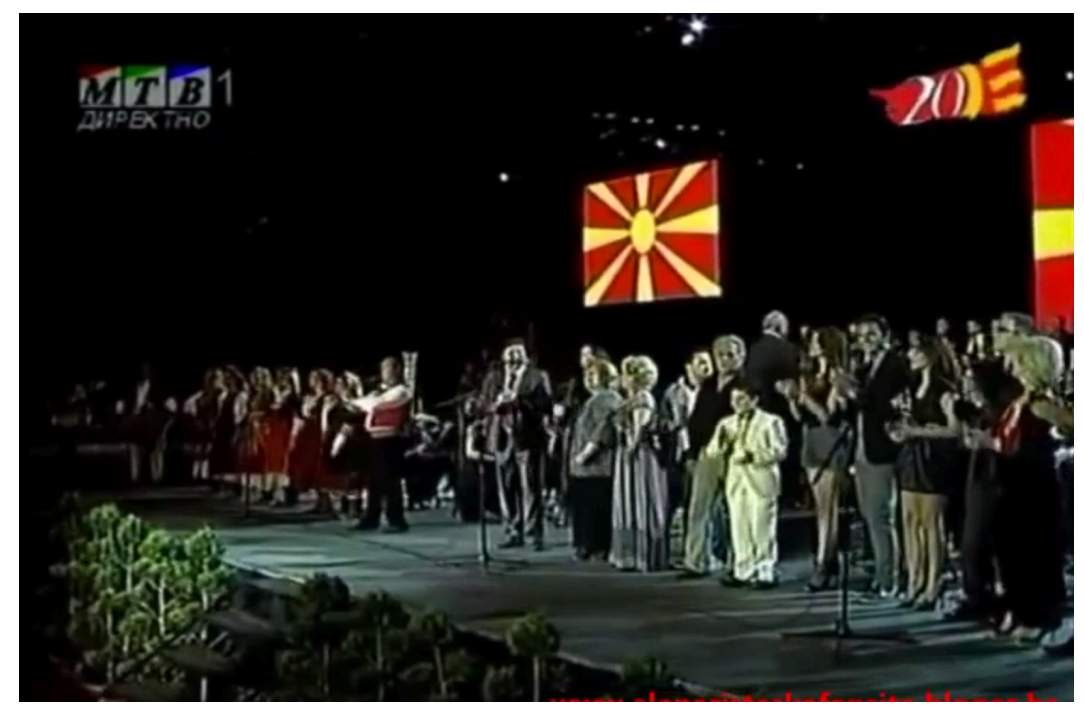

Figure 2: "Makedonija" performed by popular musicians, members of Tanec, orchestra, and choir.

See video: http://dx.doi.org/10.3998/mp.9460447.0013.202

"Makedonija" was a piece by veteran composer-arranger Kire Kostov and lyricist Miroslav Vrčakovski, the winner of a Ministry of Culture-moderated competition for a new piece to be performed at the celebration. The song was pre-recorded at the Macedonian Radio Television scoring stage (recently updated with a state-of-the art mixing board and high quality microphones through a partnership with a private French company), and included members of Tanec, the Macedonian Philharmonic, the Macedonian Opera chorus, and fifteen pop stars from various genres including Kaliopi, Karolina Gočeva, Elena Ristevska, and Suzana Spasovska. I was invited to the recording studio to observe part of the production process of the track to be used for live, television, and video playback. The recording process was completed in layers, or overdubs, whereby musical elements are recorded separately and layered over each other rather than all together in a live setting. Prior to my arrival, the Philharmonic and female vocalists of Tanec had been recorded. I observed the recording of the tapan (double-headed drum) and then the kaval (end-blown flute), which were followed by the Opera chorus and then the fifteen pop stars. Kostov supervised the production process.

After the recording team struggled to successfully place the microphone for the tapan, Kostov began instructing the tapan player on his syncopation, wanting it accented more heavily. The in-house producer chimed in to inspire the performance, saying: "Come on, this is for Macedonia!" 48 Despite

\footnotetext{
${ }^{48}$ Aside from credited performers, composers, arrangers, and lyricist, I leave my informants and other participants anonymous.
} 
the fact that Kostov is not primarily an expert on folk music, and the producer was an employee of the state-run studio as a producer of European classical music, the young musicians followed the traditional composer/producer power hierarchy and the studio system of time-efficiency, not resisting their instructions and tailoring their performance as directed. In some sense, the musicians were in the studio because they were given a directive by Džorlev, their employer at Tanec. They withheld judgment on the aesthetic value of the piece, focusing on the quality of their actual performance as a representation of their own musicianship, which would be seen and heard on national television during the celebration and on replays both on television and online.

This moment, though in a private, limited-access space (a recording studio), qualifies as public since state-appointed authority figures were present. As a result, the disposition of the musicians was that of compliant participants (though politically nonparticipatory) in the production process and its embedded nationalist ideologies. The in-house producer also may have demonstrated a performative sense of irony in the vague comment "this is for Macedonia." It was ambiguous whether the comment referenced the ancient pre-Slavic Macedonia of the cultural memory politics of the government or the patriotic Slavic conception of Macedonia fostered under Yugoslavia. The producer also performed publicly in this space, allowing the musicians and other authorities present to interpret whether the comment was ironically poking fun at the government project as kitsch, supporting the government nationalist ideology, or aligning itself more with a sense of patriotism. In any case, the comment seemed to motivate a higher-quality performance for the recording either through subtle humor or through appealing to a sense of national pride.

Moments like the one I described in the studio played out in myriad ways in other public spaces. Throughout the celebration's preparation and performance processes, performers demonstrated their social versatility while performing musical tasks of their employment in service of the production of cultural memory by the state. Here, the musicians were able to maintain their own patriotismGellner's "general loyalty" to a group-while simultaneously contributing their sonic and musical performances to a nationalist state project that promotes a reinterpretation/reconstruction of Macedonian cultural memory towards more nationalist ends, as described by Smith and Assman. Along with the producer (a position akin to a mid-level manager), they applied various heterogeneous social resources (as Sewell has it) to maintain their positions as state employees in good favor; they left no doubt about their public commitment to the state project while clearly making no room for the expression of their private views.

From my position near the stage at the celebration and in subsequent viewings of video footage, it was obvious that the performers were playing (or in some cases, miming) along with pre-recorded music that, in most cases, they had themselves recorded. The crowd of thousands filling the new square did not seem to notice or mind, as they were occupied with the thrill of seeing so many pop singers sharing the stage, and such a massive group of musicians performing together at once. Reports leading up to the celebration purported that the stage was the largest outdoor stage to ever have been erected in Macedonia, and indeed the musical performance was the largest assemblage of performers to date as well. A friend who works for the state television network told me that dozens of high definition television cameras had been rented from abroad to broadcast the event; the sweeping overhead shots of Alexander and the crowded new square presented an impressive and never before seen perspective for 
viewers throughout Macedonia intimately familiar with that space in its previous form. The unprecedented grandeur and spectacle of the event, at the very least, inspired respect for professionalism of the state production team. Because the event was planned and funded by the partyled government, Macedonian citizens associated the performance with VMRO-DPMNE, and the many people I spoke with afterwards generally praised the quality of the visual and sound production.

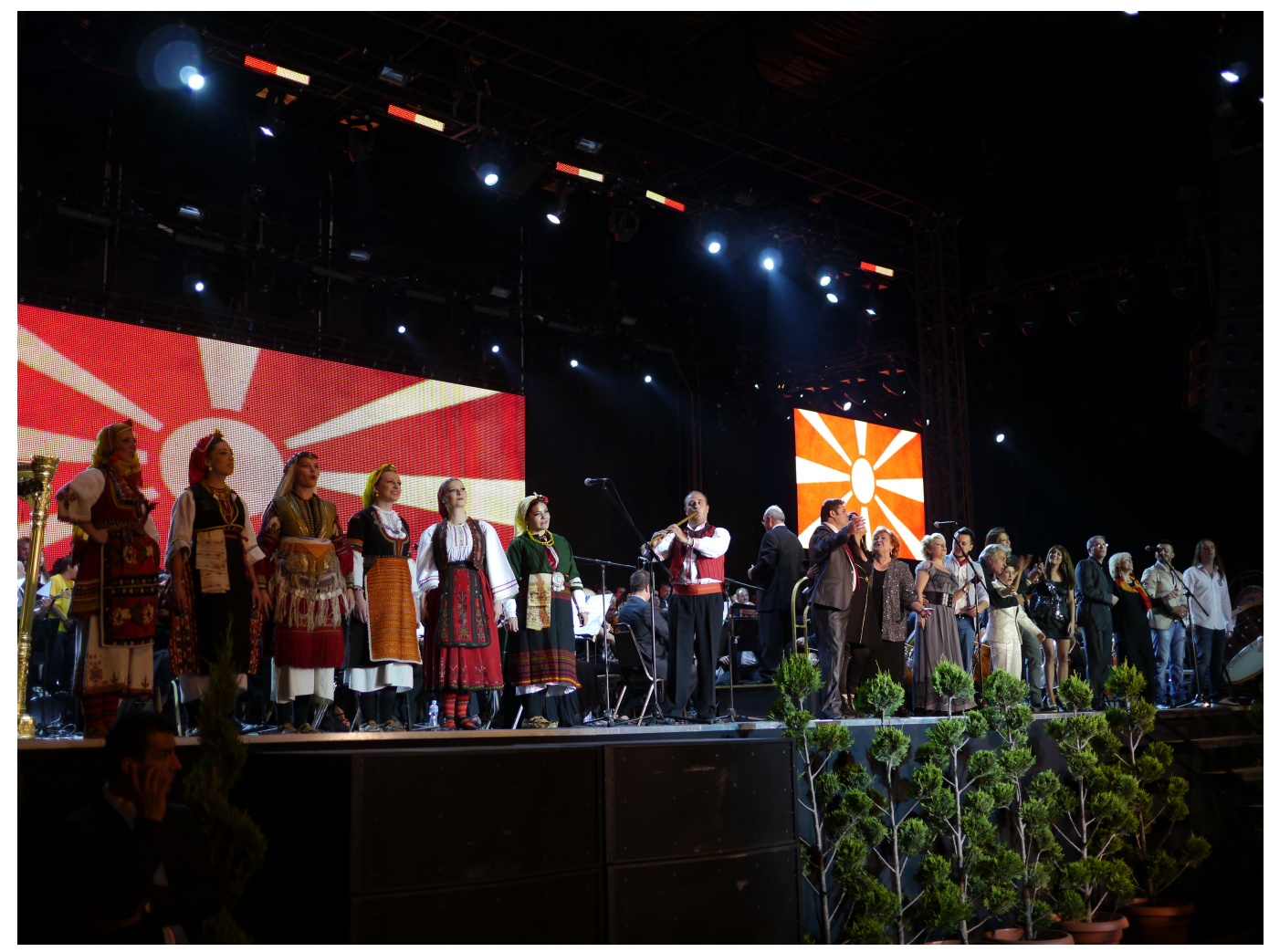

Figure 3a: Popular musicians and members of Tanec perform "Makedonija" with orchestra and choir, conducted by Kire Kostov. Photos by the author. 


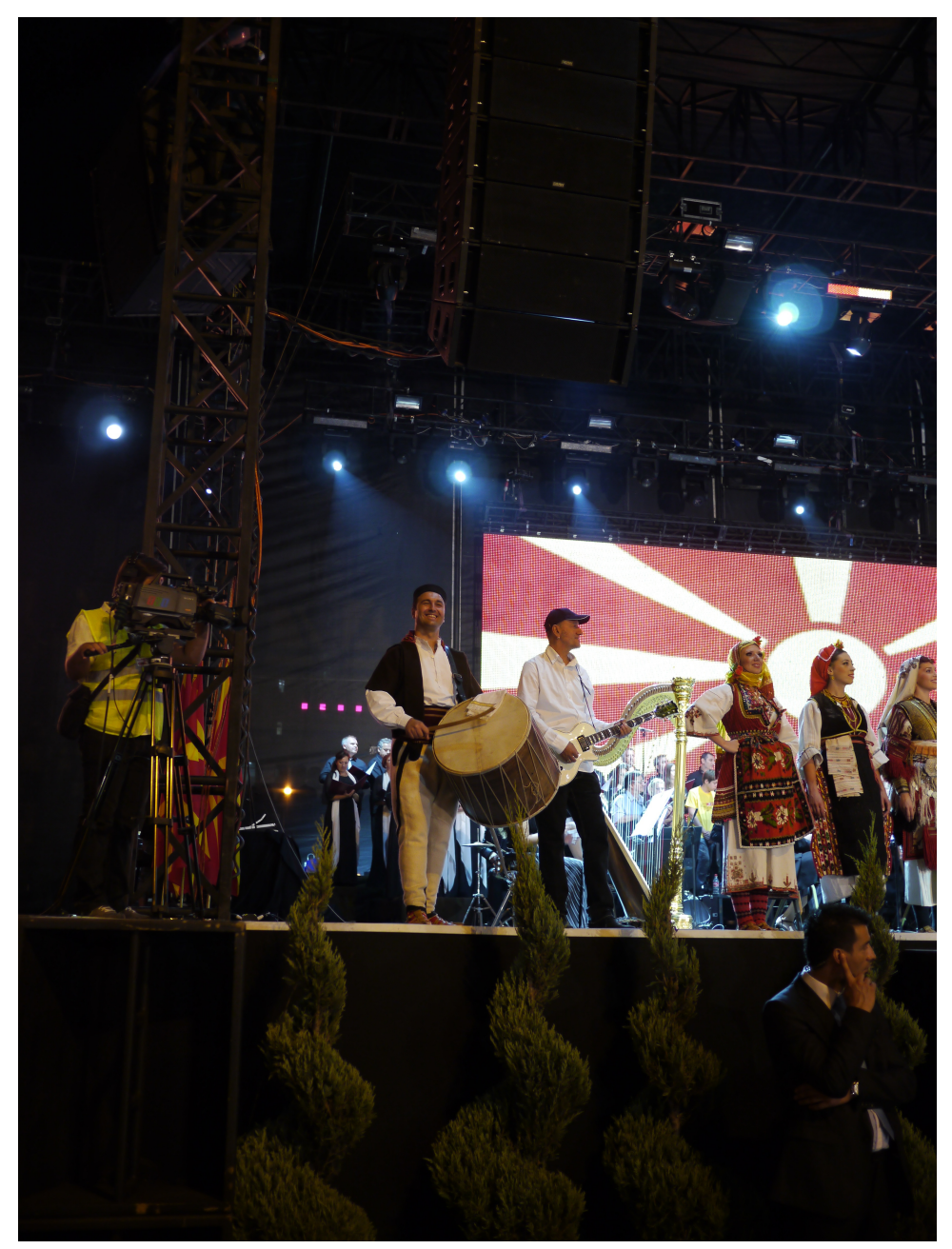

Figure 3b: (see above)

Sonic and visual markers of Macedonia littered the performance of "Makedonija," including the 7/8 meter, the presence of the kaval and tapan, the female vocalists' nasal timbre and their drone and melody texture, the folk attire of Tanec members, and the appearance of some of Macedonia's most prominent pop stars. While I was in the recording studio, Kostov conducted an interview with privately owned youth-oriented entertainment television program "Trotoar" ("Sidewalk" or "Pavement"), promoting the song. Kostov has been known for penning several pop hits in Macedonia, and in the interview (which may or may not have aired in full), Kostov mainly focused on how he hoped that this song would also become a hit, a new anthem of sorts with which the public would be able to connect. He talked about the explicit pop and folk elements as well as the presence of the Philharmonic and Opera chorus, positioning his piece as a quintessential representative of Macedonia as a country with a rich folk tradition, a vibrant European "high culture," and a viable pop and commercial music market. The interview was a seemingly innocuous publicity spot, but revealed much about the piece and the ways it publicly represents the Macedonian nation in several discourses. 
First, Kostov's invocation of Macedonia's rich (Slavic) folk culture portrays a timeless Macedonian culture, not connecting it to specific narratives of Alexander but instead, generally positioning Macedonia as a nation with a long history and, like the comment by the producer, open for the application of any nationalistic or patriotic version of Macedonian cultural memory (or any reinterpretation of history related to Smith's ideas of nation-building). Second, by highlighting the Philharmonic and Opera chorus, he positions Macedonia as modern and aligned with the oldest European musical institutions of "high culture." This not only corroborates Gellner's descriptions of nationalism, but also lines up with contemporary Macedonian public discourses about the EU accession process and ongoing efforts to prove that Macedonia belongs in the European family. Lastly, the presence of the leading pop stars from several genres and age groups suggests a thriving music and entertainment industry, a pop cultural marker that would position Macedonia as modern and cosmopolitan, also related to EU aspirations and Europeanization. Kostov, along with the Ministry of Culture jury that selected his composition, represents Macedonia generally through his music and through rhetoric about the piece. Because of previous successes in his career, he occupies relatively powerful positions in fields of cultural production, politics, and media, demonstrating his abilities in negotiating these fields and consistently situating himself favorably for personal gain and recognition while neither challenging nor enthusiastically promoting the ideologies of the state. With a long career of composing and arranging music in the Yugoslav period at Macedonian Radio Television and afterwards in state and commercial contexts, Kostov reveals himself to be an exemplary case of Sewell's versatile, knowledgeable actor who has a sophisticated understanding of how to navigate public and private spheres to the end of surviving and thriving as a known and well-respected persona in Macedonian music.

\section{"Zemjo Makedonska"}

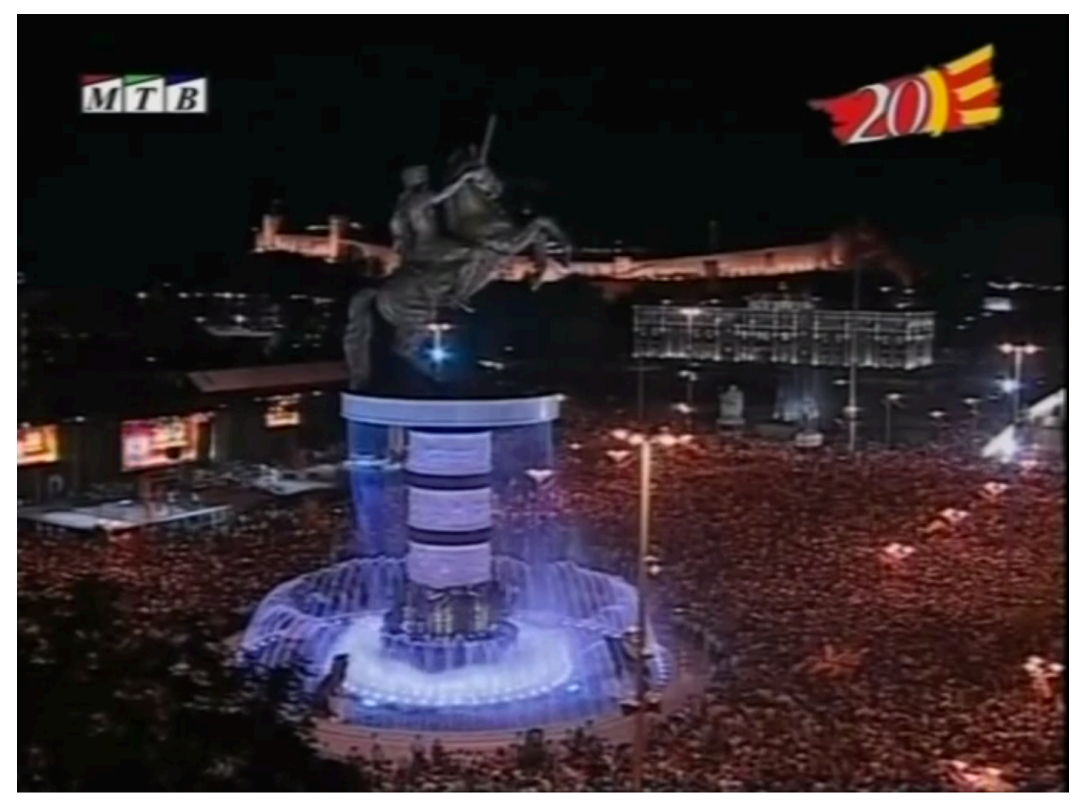

Figure 4: "Zemjo Makedonska" performed by Tanec and Zoran Džorlev. See video: http://dx.doi.org/10.3998/mp.9460447.0013.202 
Zoran Džorlev, the then-recently appointed managing director of Tanec, produced and arranged a version of "Zemjo Makedonska," a song written and popularized by renowned folk vocalist Vaska Ilieva in the 1950s. He introduced the already produced recording to the ensemble on a bus trip we were taking to a performance in early August, playing it four or five times over the bus speaker system. After hearing the electronica-dominated arrangement, full of heavy bass drum, synths, sampled tarabuka, and a violin solo by Džorlev, the reaction to the song among the musicians was muted at best (Džorlev's presence as a well-known VMRO-DPMNE ally made this a public space). This type of music is a far cry from Tanec's historical mission as Macedonia's official ensemble of folk songs and dances. Many of its musician members pride themselves in their knowledge of truly "authentic" or "izvorn" ("from the source") practices in terms of ornamentation, phrasing, and instrument building (even if prescribed ensemble practices are often stylized folklore and not always considered izvorni). Privately, ensemble members voiced disappointment with this arrangement, yet were resigned to perform it as part of their duty as Tanec employees.

The performance of this piece at the celebration involved only lip-synced singing and simulated instrumental performance, as microphones were absent and an electronic keyboard on stage with no power or sound cables attached was being played by a young man (not a member of Tanec) at arbitrary moments. As the song progressed, members of Tanec arrived on the stage one by one to form an unchoreographed, informal, fun, party atmosphere to the heavy synth drums beat and other electronic sounds. Tanec's Romani zurla (double-reed conical pipe) player mimed to a pre-recorded solo over a modified techno beat played by the tapan and some electronic drum samples, performing a level of enthusiasm similar to the other members of Tanec around him. Džorlev, who is not a usual performer in Tanec, was featured playing a violin solo, capitalizing on this opportunity to promote his own career as a musician. ${ }^{49}$ All in all, this seemed to be an attempt to bring Tanec beyond folk music into some other musical milieus in Macedonian popular consciousness.

Because this was Tanec's only performance as an ensemble at the celebration (i.e., without other collaborators), disappointment among performers and audience members familiar with Tanec's typical performance of stylized folklore was understandable. Most Macedonians I talked to found this performance distasteful, kitsch, and amateurish, not only because of its aesthetic mismatch with Tanec's standard practices, but also because none of the music was performed live, and there was no choreographed dancing. As the government-appointed director of Tanec, Džorlev had the ability to insert this musical performance into the overall program of the evening. He had spent his career in positions of influence, and less powerful individuals rarely, if ever, offered public or outspoken criticisms of his aesthetic choices. Such critiques remained in private, forming part of the alternative discourse that itself helped individual actors deal with the dissonance between their personal views and the ideologies of those in control of their employment and financial well-being.

In their public performance of the piece, the musicians and dancers of Tanec exhibited great joy

\footnotetext{
${ }^{49}$ For many years, Džorlev hosted a television program called "Zajdi, zajdi," where he featured guest folk musicians and performed with them. For an example of Macedonians performing in distinctly Romani styles, but positioning the music as Macedonian see Zoran Džorlev, "Zoran Dzorlev - Goce Dimovski: Makedonsko oro (na clarinet i saksofon)," YouTube, uploaded January 23, 2010, accessed March 25, 2013, http://www.youtube.com/watch?v=VyzHgG7Uioc.
} 
with enormous smiles on their faces, exaggerating the ways that they mimed playing instruments or singing. In this way some performers seemed to go through the motions, their bodies performing a betrayal of their knowledge of "authentic" folklore by infusing it with contemporary musical and dance practices that run contrary to the mission of Tanec. This exaggerated affect of exuberance was perceived by Macedonians I talked to as perhaps a performance with a subtle irony; in their over-thetop embodiment of enjoyment the performers could employ a form of agency to distance themselves from the content of the performance. In this way, they would be able to acknowledge and play up the kitschy aesthetic of the piece without having to verbally commit to a stance on it-and it would be understood by audience members that these performers were simply doing their job. This aesthetic seemed comparable to the oft-mentioned kitsch aesthetics of the newly unveiled Alexander fountain hovering over the stage and the numerous statues around it. As with the statues and architectural elements of Skopje 2014 unveiled at the 2011 celebration, I did not encounter any immediate criticism of this piece in media or other public forums. It received little attention in the weeks and months after the celebration-positive or negative-and became an object of nonparticipation.

\section{"Makedonium"}

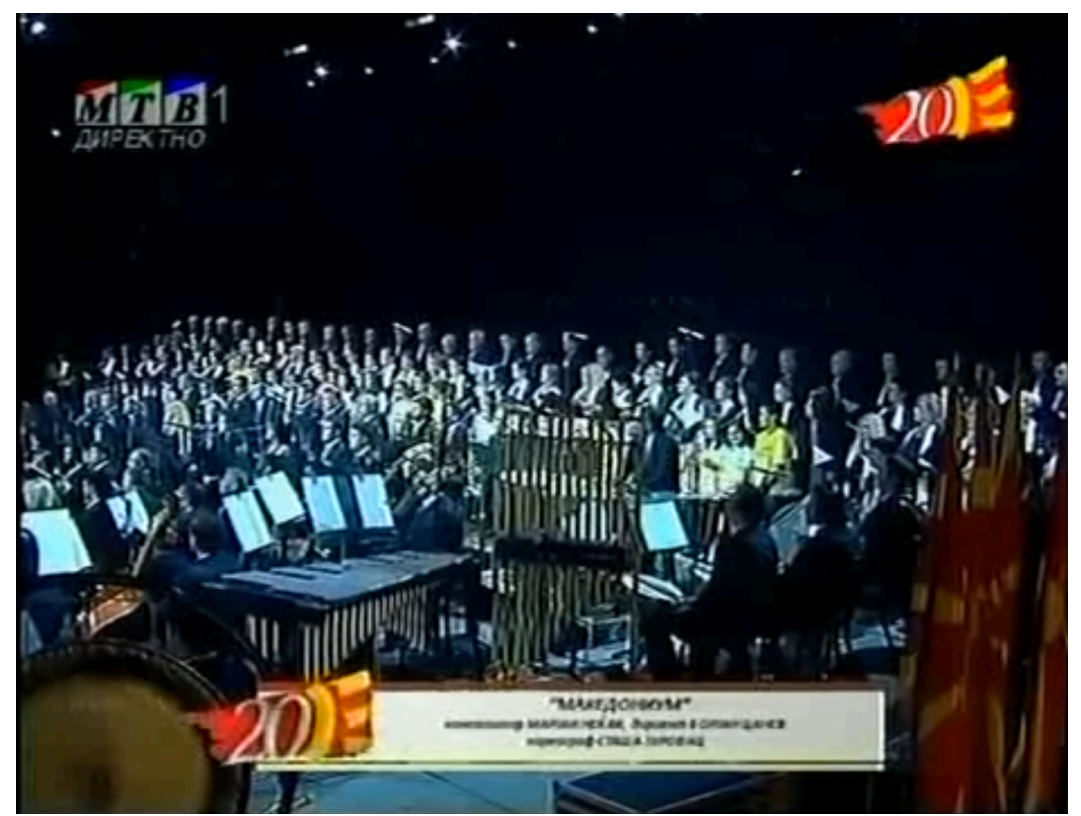

Figure 5: The performance of "Makedonium" at the celebration of twenty years of independence.

See video: http://dx.doi.org/10.3998/mp.9460447.0013.202

My final example is the central musical piece of the celebration, a "musical-stage spectacle" titled "Makedonium." ${ }^{50}$ It was composed by Marjan Nečak and involved the Macedonian Philharmonic, the Macedonian Opera Chorus, two operatic soloists, the Macedonian Ballet, a children's choir from the well-known children's television program "Zlatno Slavejče” ("Golden Nightingale”), and the musicians

\footnotetext{
${ }^{50}$ S. Gj., "Kosmopolitizmot kje caruva na 8 Septemvri” [Cosmopolitanism will rule on 8 September], Dnevnik, August 31, 2011, accessed July 15, 2012, http://www.dnevnik.com.mk/?ItemID=C80476C271A78F4E847B46A1B19156BF.
} 
and dancers of Tanec. The fourteen-minute performance combined musical and dance elements of an imagined folkloric past with the best representative music expressions of European "high culture": the orchestra, the opera, and the ballet. In Nečak's words, "The composition is a metaphor for the sun, which is a marker of Macedonia and a symbol of her birth. That is a sun, which passes through bright and dark periods, through moments of celebration, sorrow, and happiness." 51 The prima ballerina, Aleksandra Mijalkova, ${ }^{52}$ dressed in red, represented the sun and the Alexander-related ancient Macedonian past as she interacted with ballet and Tanec dancers, as well as with the operatic soloists.

The opening movement of the piece involved all of the ensembles together articulating various markers of Macedonian folk music such as 7/8 meter, a prominent amplified tapan part, and adapted oro folk dance choreography for dancers of both Tanec and the ballet. The choirs sang open vocables such as "oh" and "ah" throughout the piece in lieu of text. Soloistic harp and oboe melodies were prominent in the orchestration, an interesting choice considering that both instruments are not only emblematic of symphonic music but also employed historically to represent folk or orientalist tropes. The oboe carried the melody of Macedonian folk song "Kaleš Bre Angjo" for a substantial portion of the opening movement. This song tells the story of a Turk in Ottoman times soliciting a Macedonian girl, Angja, to join his harem. She refuses because she does not want to become Turkish, with her final line of the song reading "I don't understand Turkish" (turski ne razbiram). Though no text was used in the performance, many Macedonians would recognize the song and its subtle assertion of Macedonian identity against its principal historic foreign oppressor, consistent with anti-colonial nationalist tropes. The opening movement included one more layer of nationalist meaning in its melodic allusions to nationalist folk song "Narode Makedonski," whose familiar text is a plea to the Macedonian people to awaken and realize their identity.

An operatic duet aria constituted the second movement of the piece, reaching its conclusion as prima ballerina Mijalkova triumphantly took the hands of both vocalists, standing between them at center stage. Her position on the stage as the rising Macedonian sun clearly situated Macedonia as firmly grounded in the center of the European classical music tradition and all that it signifies. Immediately the third movement began with thematic material from the Macedonian national anthem, whose first line (though not sung) would be known by everyone in the audience: "Today over Macedonia a new sun of liberty is being born" (Denes nad Makedonija se ragja novo sonce za slobodata). The piece ended with numerous restatements of the national anthem's militaristic melody by the orchestra and choirs without stating the text, but unmistakably positioned the symphonic-folk performance as a patriotic and nationalistic amalgam of ancient Macedonian and Slavic folk pasts, a culturally relevant European present, and a hopeful future of political and economic prosperity.

\footnotetext{
${ }^{51}$ Quoted in I. N., “"Makedonium' - spektakl so 300 učesnici” [“Makedonium” - spectacle with 300 participants], Nova Makedonija, September 13, 2011, accessed March 25, 2013, http://www.novamakedonija.com.mk/NewsDetal.asp?vest=97111116452\&id=26\&setIzdanie $=22379$.

${ }^{52}$ Aleksandra Mijalkova is also the wife of Sasho Mijalkov (Nikola Gruevski's cousin, the head of the UBK, and a powerful VMRO-DPMNE politician), and her performance is frequently interpreted as political.
} 


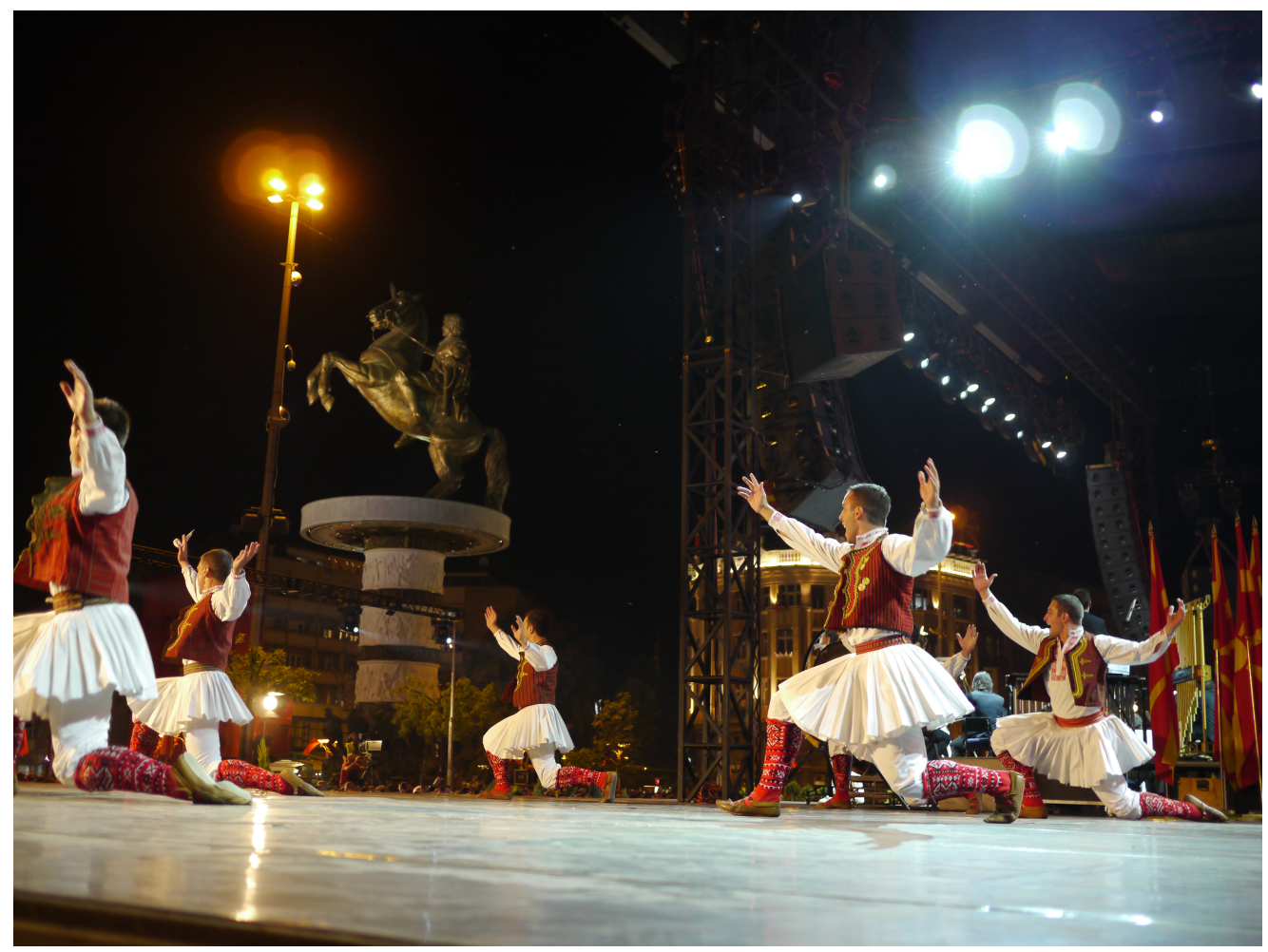

Figure 6a: Dancers from Tanec and from the Macedonian Ballet perform "Makedonium" on stage next to the Macedonian Philharmonic. Photos by the author.

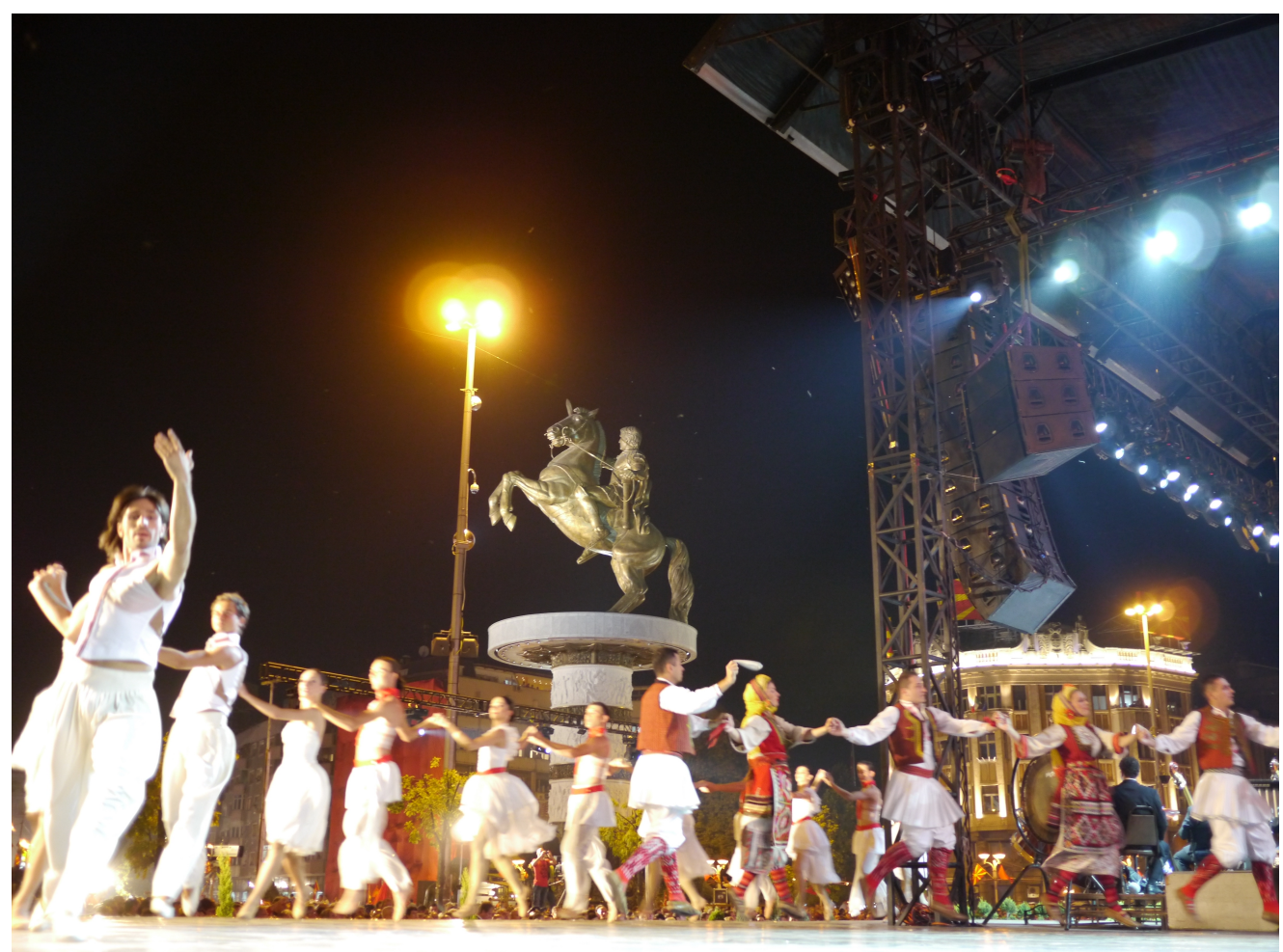

Figure 6b: (see above) 


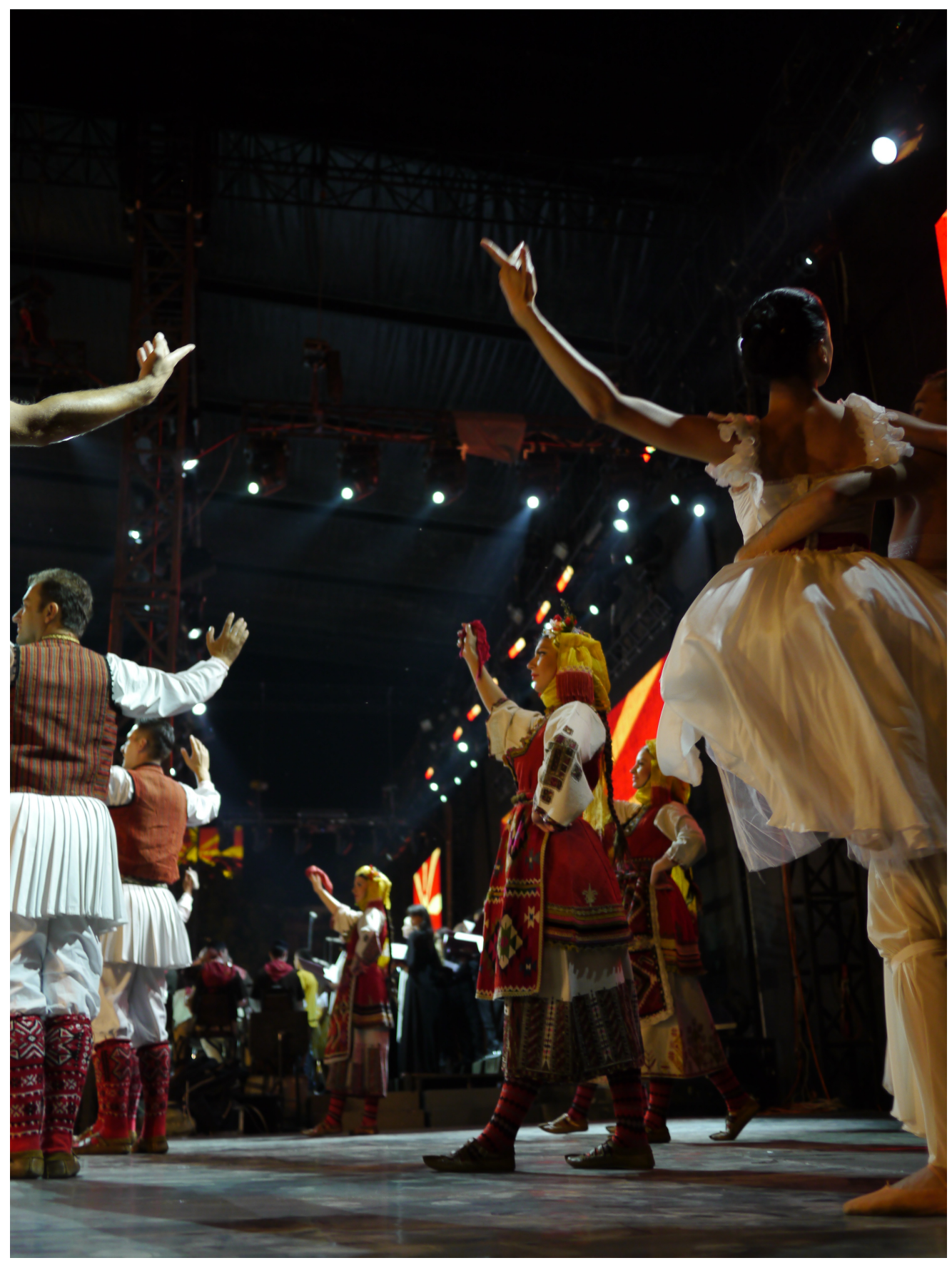

Figure 6c: (see above) 


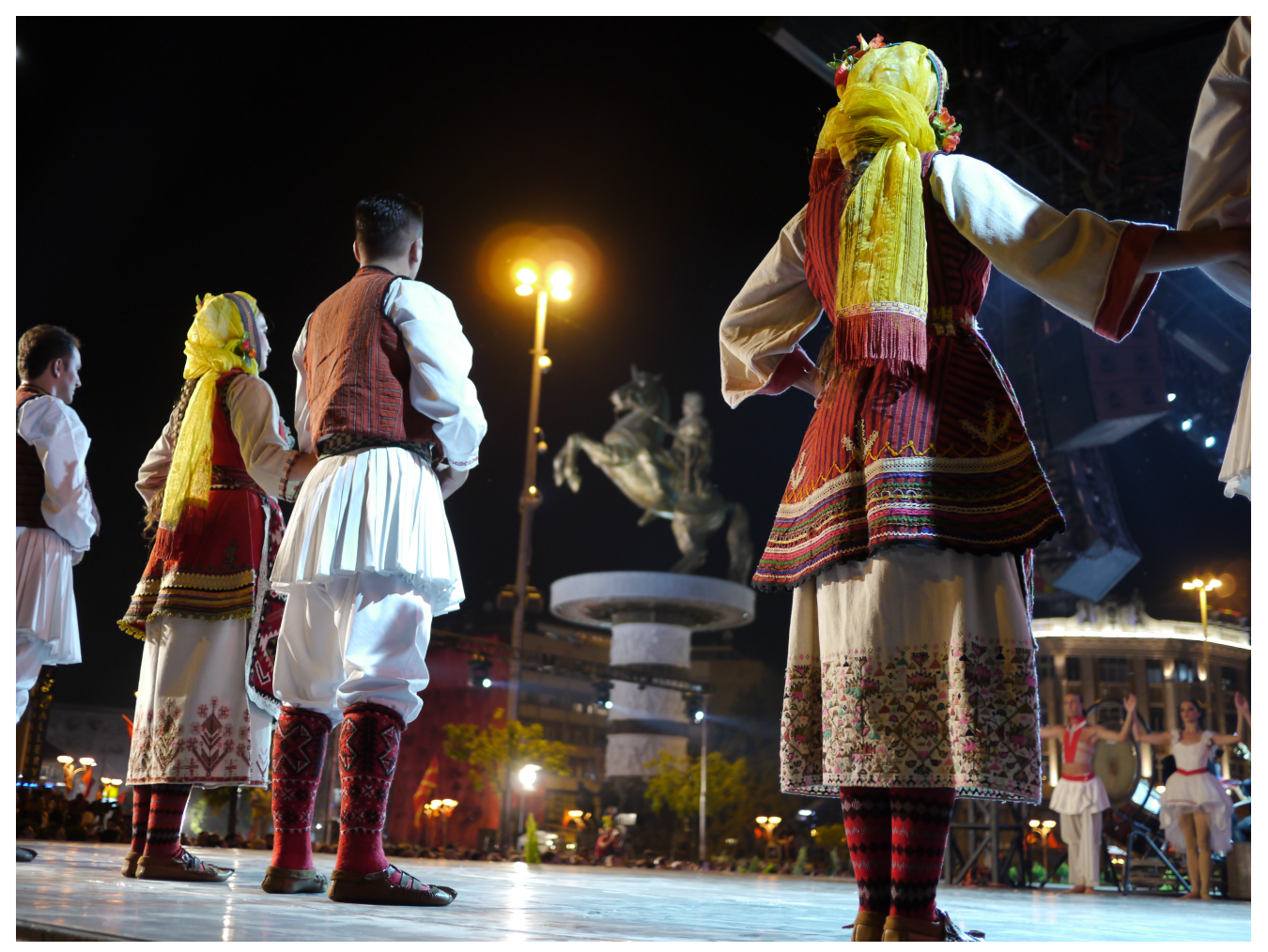

Figure 6d: (see above)

The live response to this large-scale performance was enthusiastic, at least because of its unprecedented grand scale. However, in my conversations with participants and with Macedonians who watched the performance, I encountered a more critical response. Among the opera chorus members, there was a consensus that the composition lacked originality and was too reminiscent of their recent program of music by Italian film composer Ennio Morricone. Members of the Composers Association of Macedonia (Sojuz na kompozitorite na Makedonija, or SOKOM) criticized the composition for its simplistic orchestration, which often involved unison lines or octaves for every member of the orchestra - a technique suggesting a lack of training and easily applied through copying and pasting melodies in music notation software. One orchestra musician communicated to me how excited he was to have succeeded in requesting the day off so he could enjoy the holiday and not perform the music selected for the celebration. A dancer trained in ballet told me of how famed Macedonian choreographer Risima Risimkin was replaced by Croatian Staša Zurovac for the piece, to the dismay of the Macedonian dance community. 


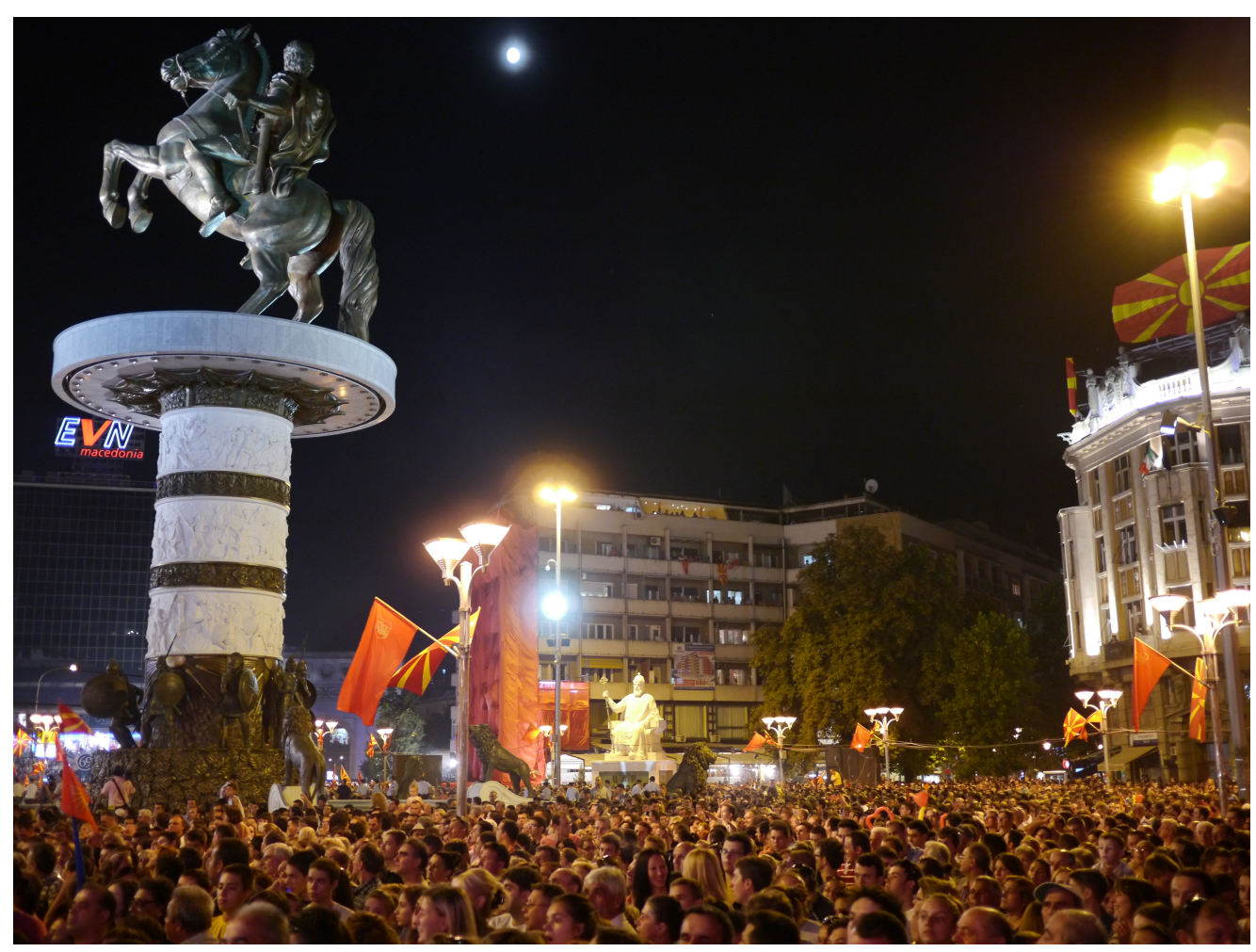

Figure 7: The audience at the celebration of twenty years of independence. Photo by the author.

Each one of these actors (and the countless others connected in some way to the performance) engaged in the private discourse that flowed beneath the surface of their public employment, expressing disappointment for the design and quality of the performance's musical and choreographic representation of Macedonia. Their patriotism and their career occupations as professionals in the arts are, in Bourdieu's terms, part of their durable dispositions (and habitus), bound as those are to the body, unable be removed without the "transformation of the conditions of the production and transformation of dispositions." As the state sought to transform the dispositions associated with Macedonia's cultural memory narrative, these individuals subtly resisted, holding onto their existing patriotism-yet only in ways that did not jeopardize their economic survival.

These types of critiques rarely appeared in media outlets and remained in the private sphere. However, composer Nečak received published criticism for what was considered amateur-level work. The president of SOKOM, Marko Kolovski, issued a statement criticizing the Ministry of Culture for unilaterally choosing (and handsomely paying) a composer who lacked adequate professional experience. SOKOM is officially an independent non-governmental association, though most of its projects depend on funding by the Ministry of Culture. As Nečak, who was not a member of SOKOM, based his three-movement composition on "Kaleš Bre Angjo," "Narode Makedonski," and the Macedonian national anthem, critics were able to pan the piece as an arrangement of existing music rather than a composition, and challenge Nečak's selection and payment for an original composition.

\footnotetext{
${ }^{53}$ Bourdieu, Pascalian Meditations, 180.
} 
Kolovski suggested that Nečak violated Macedonian folklore by passing off folk songs and the national anthem as his own work. ${ }^{54}$ Soni Petrovski, the incoming president of SOKOM at the time, was quoted in the same article affirming SOKOM's authority, asserting that the organization's criteria for membership provides assurance that members offer a high standard of composition, and hoping that the "organizers of similar meaningful events in the future will not repeat the same mistakes." 55

These critiques offered the only mass-published disapproval of the Ministry of Culture's programming for the staged celebration in Macedonia, shrewdly using the position of SOKOM as a safeguard against potential consequences for the individuals it cites and hinting that the composition is actually unpatriotic. Members of SOKOM noted that these statements received no public response from the Ministry of Culture, yet they were essential in order to indicate SOKOM's stance for future projects. Because of the necessity of SOKOM to the Ministry of Culture in its production of European classical music, its leaders were able to offer these critiques with the hopes of contributing their influence to future events and funneling Ministry funds to SOKOM members.

The leaders of SOKOM had significantly different (and more heterogeneous) resources than the musicians performing in the state ensembles; because of their more powerful position vis-à-vis the state, they could bring certain critiques into the public sphere and, in a way that small-scale protests had not, shape and correct politics of memory, albeit with a limited scope (cf. comments above on the minor protests of Skopje 2014). They used SOKOM's position as the authority on classical music composition in Macedonia to advocate for its member composers in the commissioning of new works by the state. In this way, SOKOM's leaders challenged not the cultural memory politics of the state, but rather their exclusion from participating in the production of those politics and benefitting from the funds from commissions for new works.

\section{Nationalists and Multiple Cosmopolitanisms}

An accompanying narrative to this musical celebration was one concerning cosmopolitanism. The slogan of the celebration was "20 years of statehood-20 years of independent Macedonia, together under one sun," again referencing the familiar Alexander-related symbol of the sun on the flag. Minister of Culture Elizabeta Kančeska-Milevska stated that the program would have a "cosmopolitan format and mission," and constituted a "unification of all citizens regardless of their political subjectivity, ideology, faith, or nationality, a true unification of a prosperous and enduring Republic of Macedonia." ${ }^{26}$ Each one of these performances tied distinct Macedonian musical markers to those perceived to be modern and cosmopolitan. But though some peripheral celebrations may have involved some of Macedonia's ethnic minorities, the celebration included almost exclusively ethnic Macedonian performers and music of that tradition, omitting Albanian, Romani, Turkish, and other minorities that constitute some $35 \%$ of the population.

\footnotetext{
${ }^{54}$ Tina Ivanova, "Muzički amaterizam na Denot na nezavisnosta” [Musical amateurism on the Day of independence], Utrinski, September 12, 2011, accessed July 15, 2012, http://www.utrinski.com.mk/default.asp?ItemID=8BB660702672774F96F25B3180770A5A.

${ }^{55}$ Ibid., n. p.

${ }^{56}$ S. Gj., n. p.
} 
The director of the celebration, Dejan Projkovski, also invoked cosmopolitanism to frame the event as bringing a rich national history into contemporary relevance. He asserted, "we created the concept [of the event] with the great thoughts of Goce Delčev ('I understand the world as a field of cultural competition') or of Kočo Racin ('If I haven't built a house, the whole world is a brotherly house for me'), wanting to highlight the cosmopolitan spirit of the Macedonian people [narod]. ${ }^{, 57}$ Projkovski seemed to be positing ethnic Macedonians as open to many cultures of the world, glossing over domestic ethnic relations and drawing on early twentieth-century Macedonian national heroes (Delčev and Racin) in portraying an enduring Macedonian spirit of cosmopolitanism.

These discourses draw on the common notion of cosmopolitanism as associated with middleand upper-class elites and as encompassing ideas of multi-culturalism, diversity, and modernity. Following Carol Silverman, this standard definition "clings to [cosmopolitanism's] elite and intellectual moorings" and excludes cosmopolitans such as Roma in the Macedonian case, whose cosmopolitanism is distinguished from the colloquial notion of the concept in that it "grows directly from a history of exclusion and displacement." ${ }^{58}$ This rhetoric of cosmopolitanism, then, provides an illusion of inclusion and "unification of all citizens," while inscribing boundaries of exclusion for Roma and other groups who do not seem to fit into elitist categories of what a cosmopolitan is or should be. In addition, these contemporary notions of cosmopolitanism in Macedonia have taken shape over decades-long processes of erasure of previous cosmopolitan pluralities. Sonia Seeman outlines one such process, the fashioning of the Ottoman urban musical genre čalgija into a signifier of Macedonian national identity during the Yugoslav period. In this process, sounds signifying groups "other" to ethnic Macedonians such as Roma and Turks (i.e., former colonizers) are "transformed, masked and erased in the service of signifying the nation." ${ }^{29}$ The cosmopolitanism evoked by elites in the case of the twentieth anniversary of independence celebration, then, relies on understandings of the boundaries of exclusion for who is or is not allowed to be considered equal members of a nation that participate in that nation's shared identity (in Wimmer's terms).

The performances labeled as "cosmopolitan" by elites reflect a form of what Thomas Turino terms "modernist reformism," defined as a practice that "objectifies, recontextualizes, and alters indigenous forms for emblematic purposes in light of cosmopolitan dispositions and social contexts and programs [author's emphasis]. ${ }^{60}$ Turino generalizes modernist reformism for application to nationalist movements in any context (not only in his case of Zimbabwe), and it was a clear strategy of VMRODPMNE as the party advanced its cultural memory narrative through "recontextualizing" and "altering" (or "appropriating" and "transforming" as Assman has it, see above) forms of music viewed as

\footnotetext{
${ }^{57}$ Ibid. The word narod can mean "nation," "people," and/or "folk," and, when used officially in Macedonia, usually refers to ethnic Macedonians. Cf. Donna A. Buchanan, Performing Democracy: Bulgarian Music and Musicians in Transition (Chicago: University of Chicago Press, 2006), 33-6; and Laura Olson, Performing Russia: Folk Revival and Russian Identity (New York: Routledge, 2004), 38-9, https://doi.org/10.4324/9780203317570.

${ }^{58}$ Carol Silverman, Romani Routes: Cultural Politics and Balkan Music in Diaspora (Oxford: Oxford University Press, 2012), text supplement 3.2, accessed June 12, 2019, http://global.oup.com/us/companion.websites/9780195300949/resources/10k-resources/chapter3/text/4_1/. ${ }^{59}$ Sonia Tamar Seeman, "Macedonian Calgija: A Musical Refashioning of National Identity," Ethnomusicology Forum 21, no. 3 (2012), 299, https://doi.org/10.1080/17411912.2012.699768.

${ }^{60}$ Thomas Turino, Nationalists, Cosmopolitans, and Popular Music in Zimbabwe (Chicago: University of Chicago Press, 2000), 16, https://doi.org/10.7208/chicago/9780226816968.001.0001.
} 
indigenous for this event. In the Macedonian case, it was the discursive singling out of a particular type of cosmopolitanism - one that reaffirmed the exclusion of historical and current cosmopolitan practices of Roma and other marginalized groups noted by Silverman and Seeman-that revealed how modernist reformism was at work: it positioned Macedonia favorably towards Europe through ideals of an ethnocentric national identity, modernity, and a performance of inclusivity that masked divisions and harsh inequalities. ${ }^{61}$ This discursive usage of cosmopolitanism, while inconsistent and contradictory, seems to have roots in the concept of a Kantian liberal-enlightenment subject, yet with clear boundaries excluding marginalized groups from participation in that subjectivity. Musical and other performative and rhetorical assertions of both a cultural distinctiveness and a cosmopolitan nature of ethnic Macedonians pervade the examples here and largely rely on the absence of Macedonia's ethnic others.

Postsocialist and post-Yugoslav nationalism in particular has not always emphasized cosmopolitanism, but the term has been employed in numerous ways in former Yugoslavia. Ivana Spasić provides an analysis of the use of the term as both discourse and performance in the context of contemporary southeastern Europe. Among other things, she notes that cosmopolitanism in this context is often identified with a "pro-European" stance, which favors a given country's "EU accession, progressive Europeanization of society and voluntary submission to international legal norms and institutions . . . and as against closure, isolation, xenophobia, and nationalist exceptionalism." 62 The Macedonian government elites involved in the design of the celebration used the concept (if in an inconsistent manner) in such ways, even though the musical celebration itself seemed to promote "closure, isolation, xenophobia, and nationalist exceptionalism" at various levels. Government individuals used rhetoric that implied that Macedonia was following EU accession guidelines, especially those regarding rights and representation of minority populations. Minister KančeskaMilevska's comments positioned the celebration as a cosmopolitan inclusion of all people in Macedonia regardless of faith or nationality. Director Projkovski's invocation of the cosmopolitan spirit of the Macedonian narod was more consistent with the actual artistic program, and landed closer to the heart of VMRO-DPMNE's practice of modernist reformism. His combinations of European classical music forms and Macedonian folk traditions, though they seemed to water down or even betray the legacy of both, revealed the same goals as did Alexander and the other statues that physically frame the performance. His work sought to validate both a particular cultural memory narrative where the Macedonian nation stretches back innumerable generations to antiquity (a concretion of Macedonia's identity as a "cradle" of European civilization) and the current moment in which Macedonia is a relevant and cosmopolitan part of Europe moving into the future.

Martin Stokes urges scholars to distinguish between cosmopolitanism as an "on the ground" discursive concept and cosmopolitanism as an analytical tool in scholarly analysis. I am focusing on its usage on the ground in this case, and Stokes' attention to relative positions of power in usage of the

\footnotetext{
${ }^{61}$ Silverman, Romani Routes, Seeman, "Macedonian Čalgija.”

${ }^{62}$ Ivana Spasić, "Cosmopolitanism as Discourse and Performance: A View from the Semiperiphery," Revija za sociologiju 41, no. 3 (2011), 285, https://doi.org/10.5613/rzs.41.3.1. Marina Simić, "Locating Cosmopolitanism: Practicing Popular Culture in Post-socialist Serbia," Der Donauraum 50, nos. 3-4 (2010), 345-63, https://doi.org/10.7767/dnrm.2010.50.34.345, notes another post-Yugoslav mode of cosmopolitanism.
} 
term is particularly relevant. He holds that "To evoke 'musical cosmopolitanism' is to evoke a capacity of the musical imagination, and with that word 'imagination', certain ideas about the powers, agencies, and creativities of human beings at this point in time." ${ }^{63}$ Since individuals with political power in Macedonia used the word "cosmopolitan" in reference (at least in part) to music, the performances reveal much, not only about VMRO-DPMNE's definition of cosmopolitanism, but also about the party's musical imagination and the associated ideologies, powers, agencies, and, I would add, cultural memories. Thus the musical project of VMRO-DPMNE and reactions to it must be considered in the context of the ideology the party sought to spread and the position of power it held in Macedonian society. Furthermore, it is important to consider the numerous individuals involved in political productions of national culture who held lesser positions of power as they asserted widely varying agencies and ideologies vis-à-vis those of the politically powerful, and likely exhibited and/or embodied a different type of cosmopolitanism than the type they were representing in their performances. These individuals include employees of Tanec, the Macedonian Philharmonic, the Macedonian Opera and Ballet, others performing on stage, and members of the SOKOM organization, all in a category that Jesse Ruskin and Timothy Rice have called "ordinary or typical individuals." ${ }^{64}$ These actors, dependent as they are on the state for their livelihood, seemed to associate themselves with this "official" cosmopolitanism in their stage performances.

In their critiques of the aesthetics and of other elements of government musical projects, however, these "ordinary" individuals asserted almost a superiority of taste. Because they are educated artists, they capitalized on their positions (and dispositions) in the field of cultural production to assert, at least privately, which types of music have value and originality, and which types do not. Though members of each of the ensembles were experts in their respective fields, they proved to be knowledgeable and versatile musicians as consumers (and sometimes practitioners) of many styles and genres, concurrently mindful of European "high culture" traditions, aware of trends in American pop culture, and connected to elements of Macedonian folk traditions. This privately expressed cosmopolitanism diverged from the kinds of cosmopolitanism performed at the directive of their superiors, who were party-connected individuals appointed as part of a clientelistic network and beholden to the overarching aesthetic program of the state.

In sum, the politicians in power seemed to rely on varying conceptions of cosmopolitanism, all of which served the politics of reshaping cultural memory at the site of public commemoration of the Macedonian nation. On the one hand, they defined Macedonian cosmopolitanism as multicultural, inclusive of all inhabitants of the nation-state and, by implication, linking those inhabitants to other cosmopolitan societies with similar values at least across Europe if not with an even broader scope. On the other hand, they defined it as the cosmopolitanism of an ethnic Macedonian people who exhibit openness and an ability to relate to many diverse peoples of the world. ${ }^{65}$ The musicians, like many Macedonians, exhibited cosmopolitanism in a different way. They appeared to combine both

\footnotetext{
${ }^{63}$ Martin Stokes, “On Musical Cosmopolitanism,” Macalester International Roundtable, Institute for Global Citizenship, 2007, accessed October 23, 2018, http://digitalcommons.macalester.edu/cgi/viewcontent.cgi?article =1002\&context =intlrdtable, 10.

${ }^{64}$ Jesse Ruskin and Timothy Rice, “The Individual in Musical Ethnography,” Ethnomusicology 56, no. 2 (2012), 304, https://doi.org/10.5406/ethnomusicology.56.2.0299.

${ }^{65}$ Cf. Simić.
} 
definitions articulated by the state with a musical knowledge or authority across the musical styles and genres they regularly encountered in their daily lives. With this authority, they enacted an eclectic musical cosmopolitanism, simultaneously performing and critiquing the musical creations of the state, producing (or reproducing) a disposition of more moderate Macedonian patriotism without subscribing to the state's less moderate nationalist ideologies.

\section{Music, Agency, and Contested Cultural Memory}

Turino would suggest that modernist reformism is powerful because of music's ability to accrue meaning and induce emotion, which can lead to patriotism and loyalty. ${ }^{66}$ But in light of the discussion so far, I would like to complicate the process of modernist reformism (and suggest that its power can be reduced) - not only because of the inconsistent public narrative of cosmopolitanism but also because of the agency enacted by the participants in the performance. Throughout this article I have highlighted several participants' arguably private reactions to the constructed musical representations of a national past. Although those reactions tended to be critical, most of them came from participants who seemed willing to perform their role with the appropriate (if ironic) smile or even a degree of pride. Other than Zoran Džorlev, I did not meet any musicians who were self-proclaimed VMRO-DPMNE supporters, yet most were patriotic Macedonians who considered themselves urban cosmopolitans, desired a repudiation of Greek diplomacy, and were happy to represent their country at its most significant national celebration. ${ }^{67}$ Moreover, all of the ensemble participants were financially dependent on the state for their subsistence, and received a monthly paycheck from their employment in Tanec, the Philharmonic, or the Opera chorus. Most pop singers sustained their careers through endorsement deals with private Macedonian and transnational corporations, many of whose directors (and others in positions of power) were intimately connected to political figures in the clientelistic patronage system that dominated Macedonian society and most of its employment sectors. Without protest, all of these musicians performed the power relations of the ensemble, the recording studio, or the act of performing as a featured artist, not wanting to risk their careers or the well-being of their families.

In their survival strategy, however, they publicly perpetuated, shaped, and physically embodied the dominant nationalistic regimes of memory they ostensibly opposed. Their embodied patriotism seemed to come into conflict with their bodily performance of more nationalistic ideologies; in essence, their bodies became the site of the state's struggle to transform the habitus (and the cultural memory) of ethnic Macedonians to one promoting a nationalism grounded in ancient, pre-Slavic Macedonia. Certain pasts are privileged over others in regimes of cultural memory, and in this case any "multicultural" or "non-Macedonian" past was neglected altogether despite apparent efforts to create the narrative of a multi-ethnic cosmopolitanism by the state.

My argument here is not that these musicians mindlessly enacted dominant memory politics with which they disagreed. On the contrary, they performed fully cognizant of the political narrative they were embodying, choosing to do so for their own economic survival. Simultaneously, they

\footnotetext{
${ }^{66}$ Turino, e.g., $170-77$.

${ }^{67}$ I was told that several members of the opera chorus were dedicated members of VMRO-DPMNE, which increased their job security and favor with their superiors.
} 
employed other performative and rhetorical strategies to ensure the survival of their own ideologies that diverged from (or even opposed) the ones they were perpetuating through their musical performance. These actors, to return to Sewell, applied "different and even incompatible schemas" as they maintained, and indeed embodied, multiple dissimilar cultural memory narratives concurrently. ${ }^{68}$

The examples from Macedonia's celebration of independence reveal much about music's role in the contestation of memory narratives. I would suggest that there are at least three distinct and interrelated ways music provides a vehicle for individuals to exercise agency in opposition to prevalent ideologies, even when those ideologies are mobilized through musical performance. First, though the government holds power over its employees in this case, musicians must possess a specialized skill in order to be hired for a position, and are not as subject to the political clientelism and nepotism ubiquitous in hiring practices in other fields. In this instance, they are less motivated by the threat of unemployment to support VMRO-DPMNE. Thus, they may find it easier to bemoan, if privately, their responsibility to perform VMRO-DPMNE's aesthetic musical strategies or to withhold passion and excitement in performances. Second, music constructed for celebration of the nation (like statues and monuments), is a reified cultural entity, an object available for judgment and the expression of disapproval of a government project as kitschy or amateurish. In this way the public can criticize extreme nationalist ideologies without having to name them or their proponents explicitly. While various comments sections of YouTube recordings of the performances discussed above contain mostly nationalistic support of the celebration and angry comments from Greeks and others decrying Macedonian ownership of symbols like Alexander the Great, sectors of the Macedonian public maintained discourse critical of nationalist ideologies in personal conversation and other nonpublishable forums. ${ }^{69}$ Third, and perhaps most powerful, musicians and the public play roles in the mechanisms of distribution and consumption of music. Pop stars did not promote Kire Kostov's "Makedonija" beyond September 8, YouTube views of the performances failed to reach significant numbers, and the state television network was the only media outlet to rebroadcast the performances. By these means, individuals demonstrated a passive rejection of these nationalist memory politics (again, nonparticipation), hindered the distribution and consumption of the ideologies of memory embedded in musical products, and in effect minimized the power of these cultural memory narratives by preventing influence on the aesthetic and political sensibilities of the public.

Perhaps the musical spectacles of VMRO-DPMNE were too extreme, did not come across as cosmopolitan in the way that the party intended, or simply did not strike the right chord with the public. VMRO-DPMNE's real power was economic in controlling an individual's ability to earn income, but music gave people a position to counter the VMRO-DPMNE narrative of Macedonia without it being a risk to their livelihood. I would argue that many Macedonians supported a more moderate, patriotic narrative and embodied a different variation of cosmopolitanism than those put

\footnotetext{
${ }^{68}$ Sewell, 140.

${ }^{69}$ In the comments on a YouTube video of "Zemjo Makedonska," comments range from one stating "a most beautiful song; long live Macedonia! [najubava pesna; da Živee Makedonija!]" to others stating that there is no connection between Macedonia and Alexander the Great. "NU Tanec-Makedonija \& Dzorlev Zoran 'ZEMJO MAKEDONSKA," September 10, 2011, accessed March 18, 2019, https://youtu.be/CYbmA1tHzQ0. My time as an ethnographer in musical and other circles included countless conversations critical of nationalistic ideologies in cafés, bars, and other settings experienced as informal or private.
} 
forth by VMRO-DPMNE. In fact, after the central celebration, popular Macedonian musicians of all genres performed their standard repertoire on the square late into the night, and the pop music videos of late Balkan superstar Toše Proeski had played on the state television network throughout the day. These artists represented Macedonia simply by positioning themselves as unequivocally Macedonian and by performing in the Macedonian language-enough to garner the support of a patriotic public regardless of political affiliation.

Because VMRO-DPMNE had gained great political and economic power in Macedonian society, it was able to reconfigure public space with statues and dictate the visual and aural content of this national celebration in an attempt to recreate Macedonian cultural memory. But music provided a unique way for both musicians and the public to challenge or at least suffer the party's antiquization projects that reimagined the past and its modernist reformism that sought to shape the future through that reimagining. Even as the party lost its grip on power in Macedonia in the years following this celebration, many Macedonians continued to embrace (or simply tolerate) the party for reasons of personal economic survival or lack of a viable alternative. Yet regardless of who holds power, as long as people find ways to creatively maintain their own memory narratives through strategies such as irony, discourse in the private sphere, decisions of consumption, self-positioning as particular types of cosmopolitans, and possibly others not yet developed, their narratives—while perhaps hidden-will persist as living and viable alternatives to the dominant ones emanating from political centers of power. 


\section{Bibliography}

Anderson, Benedict. Imagined Communities: Reflections on the Origin and Spread of Nationalism. New edition. London: Verso Books, 2006.

Angelovska, Despina. “(Mis)representations of Transitional Justice: Contradictions in Displaying History, Memory, and Art in the Skopje 2014 Project.” In The Arts of Transitional Justice: Culture, Activism, and Memory after Atrocity, edited by Peter Rush and Olivera Simić, 173-93. New York: Springer, 2014. https://doi.org/10.1007/978-1-4614-8385-4_10.

Assman, Jan. "Collective Memory and Cultural Identity." Trans. by John Czaplika. New German Critique 65 (1995): 125-33.

Banac, Ivo. The National Question in Yugoslavia: Origins, History, Politics. Ithaca, NY: Cornell University Press, 1984.

Bourdieu, Pierre. The Logic of Practice. Stanford, CA: Stanford University Press, 1990.

. Pascalian Meditations. Stanford, CA: Stanford University Press, 2000.

Brown, Keith. The Past in Question: Modern Macedonia and the Uncertainties of Nation. Princeton, NJ: Princeton University Press, 2003.

Brubaker, Rogers. Nationalism Reframed: Nationhood and the National Question in the New Europe. New York: Cambridge University Press, 1996. https://doi.org/10.1017/CBO9780511558764.

Buchanan, Donna A. Performing Democracy: Bulgarian Music and Musicians in Transition. Chicago: University of Chicago Press, 2006.

CIA Factbook. "Macedonia,” 2012. Accessed August 15, 2018. https://www.cia.gov/library/publications/the-world-factbook/geos/mk.html.

Danforth, Loring M. The Macedonian Conflict: Ethnic Nationalism in a Transnational World. Princeton, NJ: Princeton University Press, 1995.

Dimovski, Sase, and Sinisa Jakov Marusic. "Macedonia's A1 TV Owner Jailed for 13 Years," BalkanInsight, March 14, 2012. Accessed December 18, 2013. http://www.balkaninsight.com/en/article/aa3-yearsin-jail-for-macedonia-s-aaa-tv-owner.

Dodovski, Ivan. "Pride and Perplexities: Identity Politics in Macedonia and Its Theatrical Refractions." In After Yugoslavia: Identities and Politics within the Successor States, edited by Robert Hudson and Glenn Bowman, 92-104. New York: Palgrave Macmillan, 2012. https://doi.org/10.1057/9780230305137_6.

Dunin, Elsie Ivančić, and Stanimir Višinski. Dances in Macedonia: Performance Genre, Tanec. Skopje: Open Society Institute Macedonia, 1995.

Džorlev, Zoran. “Zoran Dzorlev - Goce Dimovski: Makedonsko oro (na clarinet i saksofon).” YouTube, uploaded January 23, 2010. Accessed March 25, 2013. http://www.youtube.com/watch?v=VyzHgG7Uioc.

Gal, Susan. "A Semiotics of the Public/Private Distinction." differences: A Journal of Feminist Cultural Studies 13, no. 1 (2002): 77-95. https://doi.org/10.1215/10407391-13-1-77.

Garcelon, Marc. "The Shadow of the Leviathan: Public and Private in Communist and Post-Communist Society." In Public and Private in Thought and Practice: Perspectives on a Grand Dichotomy, edited by Jeff Weintraub and Krishan Kumar, 303-32. Chicago: University of Chicago Press, 1997.

Gellner, Ernest. Nationalism. London: Weidenfeld \& Nicolson, 1997. . Nations and Nationalism. Second edition. Ithaca, NY: Cornell University Press, 2006. 
Gj, S. "Kosmopolitizmot kje caruva na 8 Septemvri." [Cosmopolitanism will rule on 8 September.] Dnevnik, August 31, 2011. Accessed July 15, 2012. http://www.dnevnik.com.mk/?ItemID=C80476C271A78F4E847B46A1B19156BF.

Graan, Andrew, "Counterfeiting the Nation?: Skopje 2014 and the Politics of Nation Branding in Macedonia." Cultural Anthropology 28, no. 1 (2013): 161-79. https://doi.org/10.1111/j.15481360.2012.01179.x.

Greenberg, Jessica. “'There's Nothing Anyone Can Do about It': Participation, Apathy, and 'Successful' Democratic Transition in Postsocialist Serbia." Slavic Review 69, no. 1 (2010): 41-64. https://doi.org/10.1017/S0037677900016697.

Hechter, Michael. Containing Nationalism. Oxford: Oxford University Press, 2000. https://doi.org/10.1093/019924751X.001.0001.

Hofman, Ana. "Socialist Stage: Politics of Place in Musical Performance." New Sound36, no. 2 (2010): $120-34$.

- Staging Socialist Femininity: Gender Politics and Folklore Performance in Serbia. Boston: Brill, 2011. https://doi.org/10.1163/ej.9789004191792.i-148.

Ivanova, Tina. "Muzički amaterizam na Denot na nezavisnosta." [Musical amateurism on the Day of independence.] Utrinski, September 12, 2011. Accessed July 15, 2012. http://www.utrinski.com.mk/default.asp?ItemID=8BB660702672774F96F25B3180770A5A.

Jezernik, Božidar. "No Monuments, No History, No Past: Monuments and Memory." In After Yugoslavia: Identities and Politics within the Successor States, edited by Robert Hudson and Glenn Bowman, 182-91. New York: Palgrave Macmillan, 2012. https://doi.org/10.1057/9780230305137_12.

Kharkhordin, Oleg. "Reveal and Dissimulate: A Genealogy of Private Life in Soviet Russia." In Public and Private in Thought and Practice: Perspectives on a Grand Dichotomy, edited by Jeff Weintraub and Krishan Kumar, 333-63. Chicago: University of Chicago Press, 1997.

Kinert, Albert and Dragutin Zdunić. Folklor Naroda Jugoslavije. Zagreb: Grafički Zavoda Hrvatske, 1963.

Laušević, Mirjana. "The Ilahiya as a Symbol of Bosnian Muslim National Identity.” In Retuning Culture: Musical Changes in Central and Eastern Europe, edited by Mark Slobin, 117-135. Durham, NC: Duke University Press, 1996. https://doi.org/10.1215/9780822397885-008.

Mann, Michael. "A Political Theory of Nationalism and its Excesses." In Notions of Nationalism, edited by Sukumar Periwal, 44-64. Budapest: Central European University, 1995.

Mattioli, Fabio. "Regimes of Aesthetics: Competing Performances Surrounding the Skopje 2014 Plan.” In Mirroring Europe: Ideas of Europe and Europeanization in Balkan Societies, edited by Tanja Petrović, 64-87. Leiden: Brill, 2014. https://doi.org/10.1163/9789004275089_005.

- "Financialization without Liquidity: In-kind Payments, Forced Credit, and Authoritarianism at the Periphery of Europe." Journal of the Royal Anthropological Institute 24 (2018): 568-88. https://doi.org/10.1111/1467-9655.12861.

Mijatovic, Brana. "The 'Supermen' and the 'Normal People': Music, Politics, and Tradition in 1990s Serbia." Selected Reports in Ethnomusicology 12 (2005): 203-18.

N, I. "'Makedonium' - spektakl so 300 učesnici." [“Makedonium” - spectacle with 300 participants.] Nova Makedonija. September 13, 2011. Accessed March 25, 2013. http://www.novamakedonija.com.mk/NewsDetal.asp?vest $=97111116452 \& \mathrm{id}=26 \&$ setIzdanie $=2237$ 9 . 
Neofotistos, Vasiliki P. "Going Home to Pakistan: Identity and Its Discontents in Southeastern Europe." Identities 18, no. 4 (2011): 291-316. https://doi.org/10.1080/1070289X.2011.654102.

- The Risk of War: Everyday Sociality in the Republic of Macedonia. Philadelphia: University of Pennsylvania Press, 2012. https://doi.org/10.9783/9780812206562.

Nohlen, Dieter, and Philip Stöver. Elections in Europe: A Data Handbook. Baden-Baden, Germany: Nomos, 2010. https://doi.org/10.5771/9783845223414.

Nora, Pierre. Les Lieux de Mémoire. [Realms of Memory.] Vol. 2, La Nation [The Nation.] Paris: Gallimard, 1986.

— . "Between Memory and History: Les Lieux de Mémoire." Representations 26 (1989): 7-25. https://doi.org/10.2307/2928520.

Oberschall, Anthony. "The Manipulation of Ethnicity: From Ethnic Cooperation to Violence and War in Yugoslavia." Ethnic and Racial Studies 23, no. 6 (2000): 982-1001. https://doi.org/10.1080/014198700750018388.

Olson, Laura J. Performing Russia: Folk Revival and Russian Identity. New York: Routledge, 2004. https://doi.org/10.4324/9780203317570.

Opetčeska Tatarčevska, Ivona. “The Idea Behind Our Folk Dances’: Public Narratives About Folk Dances in Macedonia." In ICTM Study Group on Music and Dance in Southeastern Europe: Proceedings 2010 Symposium Izmir, Turkey, edited by Elsie Ivančić Dunin, 78-85. Izmir, Turkey: ICTM Study Group on Music and Dance in Southeastern Europe, 2010.

Ortner, Sherry B. Anthropology and Social Theory: Culture, Power, and the Acting Subject. Durham, NC: Duke University Press, 2006. https://doi.org/10.1215/9780822388456.

Phillips, John. Macedonia: Warlords And Rebels in the Balkans. New Haven, CT: Yale University Press, 2004.

Poulton, Hugh. Who are the Macedonians? Bloomington: Indiana University Press, 1995.

Rasmussen, Ljerka Vidić. "The Southern Wind of Change: Style and the Politics of Identity in Prewar Yugoslavia." In Retuning Culture: Musical Changes in Central and Eastern Europe, edited by Mark Slobin, 99-116. Durham, NC: Duke University Press, 1996. https://doi.org/10.1215/9780822397885-007.

Rossos, Andrew. Macedonia and the Macedonians: A History. Stanford, CA: Hoover Institution Press, 2008.

Ruskin, Jesse, and Timothy Rice. "The Individual in Musical Ethnography.” Ethnomusicology56, no. 2 (2012): 299-327. https://doi.org/10.5406/ethnomusicology.56.2.0299.

Seeman, Sonia Tamar. "Macedonian Calgija: A Musical Refashioning of National Identity." Ethnomusicology Forum 21, no. 3 (2012): 295-326. https://doi.org/10.1080/17411912.2012.699768.

Sewell, William H., Jr. Logics of History: Social Theory and Social Transformation. Chicago: University of Chicago Press, 2005. https://doi.org/10.7208/chicago/9780226749198.001.0001.

Silverman, Carol. Romani Routes: Cultural Politics and Balkan Music in Diaspora. Oxford: Oxford University Press, 2012.

Simić, Marina. "Locating Cosmopolitanism: Practicing Popular Culture in Post-socialist Serbia." Der Donauraum 50, nos. 3-4 (2010): 345-63. https://doi.org/10.7767/dnrm.2010.50.34.345.

Smith, Anthony D. The Ethnic Origins of Nations. Oxford, UK: Basil Blackwell, 1988. 
Spasić, Ivana. "Cosmopolitanism as Discourse and Performance: A View from the Semiperiphery.” Revija za sociologiju 41, no. 3 (2011): 269-90. https://doi.org/10.5613/rzs.41.3.1.

Stokes, Martin. "On Musical Cosmopolitanism.” Macalester International Roundtable. Institute for Global Citizenship, 2007. Accessed October 23, 2018.

http://digitalcommons.macalester.edu/cgi/viewcontent.cgi?article $=1002 \&$ context $=$ intlrdtable.

Sugarman, Jane C. “'The Criminals of Albanian Music': Albanian Commercial Folk Music and Issues of Identity since 1990." In Balkan Popular Culture and the Ottoman Ecumene: Music, Image, and Regional Political Discourse, edited by Donna A. Buchanan, 269-307. Lanham, MD: Scarecrow Press, 2007.

Tilly, Charles. "States and Nationalism in Europe, 1492-1992." Theory and Society 23 (1994): 131-46. https://doi.org/10.1007/BF00993675.

Turino, Thomas. Nationalists, Cosmopolitans, and Popular Music in Zimbabwe. Chicago: University of Chicago Press, 2000. https://doi.org/10.7208/chicago/9780226816968.001.0001.

Verdery, Katherine. What Was Socialism, and What Comes Next? Princeton, NJ: Princeton University Press, 1996.

Volčič, Zala. "Yugo-Nostalgia: Cultural Memory and Media in the Former Yugoslavia." Critical Studies in Media Communication 24, no. 1 (2007): 21-38. https://doi.org/10.1080/07393180701214496.

Weintraub, Jeff, and Krishan Kumar, eds. Public and Private in Thought and Practice: Perspectives on a Grand Dichotomy. Chicago: University of Chicago Press, 1997.

Wilson, Dave. "Music Making Space: Musicians, Scenes, and Belonging in the Republic of Macedonia." PhD diss., University of California, Los Angeles, 2015.

Wimmer, Andreas. Waves of War: Nationalism, State Formation, and Ethnic Exclusion in the Modern World. Cambridge: Cambridge University Press, 2013. https://doi.org/10.1017/CBO9781139198318.

- "Why Nationalism Works and Why It Isn't Going Away." Foreign Affairs 98, no. 2 (2019).

Accessed June 11, 2019. https://www.foreignaffairs.com/articles/world/2019-02-12/why-nationalismworks.

Wimmer, Andreas, and Yuval Feinstein. "The Rise of the Nation-State across the World, 1816 to 2001." American Sociological Review 75, no. 5 (2010): 764-90. https://doi.org/10.1177/0003122410382639.

"Yugoslav National Folk Ballet (Tanec): First American Tour." Official concert program. New York: Lou Dunetz and Paul Lovett, 1956. 


\section{Acknowledgements}

I am grateful to all of the named and unnamed musicians in this article, who generously shared time, space, and music with me in the course of this research. Funding for this research was provided by the American Council of Learned Societies, the American Councils for International Education, and the UCLA Graduate Division. I would also like to thank Ana Hofman, Thomas Hilder, and two anonymous reviewers for their immensely helpful comments on earlier drafts of this article. All interpretations, errors, and omissions are mine alone. 